\title{
Study on the Possibility of Mixed Water as a Drinking Water
}

\section{-From the Viewpoint of the Formation of Hydrogen-Rich Water}

\author{
Akira Hiratsuka1 ${ }^{*}$, Yoshiro Yasuda² \\ ${ }^{1}$ Former University Scholar in Environmental Systems, Kyoto, Japan \\ ${ }^{2}$ Management, University of Hyogo, Kobe, Japan \\ Email: *ugj4339@iris.eonet.ne.jp
}

How to cite this paper: Hiratsuka, A. and Yasuda, Y. (2021) Study on the Possibility of Mixed Water as a Drinking Water-From the Viewpoint of the Formation of Hydrogen-Rich Water. Journal of Water Resource and Protection, 13, 44-73. https://doi.org/10.4236/jwarp.2021.131004

Received: December 26, 2020

Accepted: January 26, 2021

Published: January 29, 2021

Copyright $\odot 2021$ by author(s) and Scientific Research Publishing Inc. This work is licensed under the Creative Commons Attribution-NonCommercial International License (CC BY-NC 4.0). http://creativecommons.org/licenses/by-nc/4.0/ (c) (i) (3) Open Access

\begin{abstract}
In exploring an autonomous independent water supply system, authors have realized the importance of the sustainable water supply utilizing regional features in isolated islands. This paper is further study from the previous one. This time we have narrowed down the mixing rate of mixed water. In this study, the mixed water less than $0.74 \%$ (blood concentration) has been prepared first, and then divided it into five kinds of the mixing rate of mixed water. And we have compared and examined the characteristics of the mixed water from the viewpoint of the relationship between salinity and $\mathrm{pH}$, ORP and that of Dissolved Hydrogen, and examined the possibility of mixed water as a drinking water. As a result, we have obtained the new findings that suggest the possibility.
\end{abstract}

\section{Keywords}

Seawater, Rainwater, Hydrogen-Rich Water, Magnesium $\left(\mathrm{Mg}^{2+}\right)$, Food Additives

\section{Introduction}

Mithen Steven J. (world-renowned archaeologist, $\mathrm{PhD}$ ) has left a wise saying that "The water supply to oneself should be controlled by oneself" (Intent) about the water management history of humankind in his book [1]. The water supply issue with/post Covid-19 crisis in the world will become increasingly severe. At present, the number of people who want to live in the countryside is increasing with corona crisis in the progression of teleworking. According to the survey on attitude toward regional migration by the cabinet office (Cabinet Office, July 2020), the parsons living in Tokyo in one's 20s who are concerned with the mi- 
gration were $35.4 \%$ [2].

This is a desirable way as a new one's lifestyle in a sense. From the viewpoint of the waterworks, however, this directly results in the problem that the more local immigrants increase, the more water charge one has. As everybody knows, the charge calculation system of the waterworks has been decided by the cost such as facility maintenance fee, operating expenses, wholesale water cost etc. (numerator) and population served by piped water (denominator). Therefore, as population served by piped water (denominator) decreases, the water charges increase necessarily. Furthermore, as has already been said in waterworks, there exist various nasty issues that occurred from the decrease of accounted-for water, the decrepit of the facilities, the decrease of the waterworks staff, the privatization and re-publicization in waterworks etc. [3]. In addition to that, there exists an issue of the decrease of food self sufficiency rate too. Japan is poor in natural resources, and is heavily dependent on the imports from all over the world including China for a while. However, at present the food safety problems have occurred in China. And looking at the relationship between the United States (US as America First) and China in the future, the economic conflict between the US and Japan over the trade through China-US trade war will might break out. Therefore, it is important to make the agriculture prosperous (primary sector of industry) so that Japan may become independent. That is, it is thought that it is the most important to us now that we should ratchet up the flow of a new style agricultural corporation which is an organization that manages agricultural activities.

Here, we briefly would like to confirm the history on Japan's agrarian reforms [4]. It is said that the prewar peasants in Japan were tenant farmers who mostly do not have their own land. They grew crops by renting a farmland and paying farm rent to a landlord, and they had been strictly exploited from the parasitic landlord. The agricultural land reform GHQ (General Headquarters) launched was carried out after World War II. This reform means the confiscation of farmland by the government virtually, and the peasants were made self-made farmers. This system went well until the period of high economic growth (1954-1970). However, when it comes to a high growth, the income gap between the industrial workers who work in a city and the farmers came to arise. As a result, the number of farmers has decreased. It means a decline in the farming population due to high economic growth. Therefore, the agricultural fundamental law (1961) was established by the government to reduce the income gap. Although the income was increased by the law, the debts have been piled up by the mechanization of agriculture. Thus, in 1995 the idea of a liberalization of agriculture was brought after abolishing the foodstuff control law (established in 1942). On these backgrounds, the new agricultural foundation law was established in 1999. This law recommends the marketing principle (market mechanism). This expresses the introduction of the agriculture system such as a large-scale management of the American Family-runs are principle in Japanese modern agriculture. How- 
ever, the employment of cheap workers from overseas due to large trading cap companies etc. acted gradually as a spur to the decreasing of Japanese agriculture population.

Looking back on Japan's historical background of the agriculture, it is understood that the farm family involved in another business on the side due to the marketing principle was increased. What we call "Sanchan nogyo (farming without a master of a family; farming by 'mommy, grandpa and grandma')" revolved around their works. That is the reason why it was difficult to produce the successor. The agriculture was just a stage of going to the wall, and will be faced with a bleak future. Regarding this, it can be said that the matter in which the incorporation of agriculture has not smoothly made any progress so far is considered to be one of the biggest causes (a major political issue) [5]. In this way, the decrease of agricultural population, an aging of the population and a shortage of successors have arisen, and they have at present become a big problem in agricultural sector.

By the way, at the present stage the population of new farmers aged 49 or younger seems to have been on the increase actually [6]. The breakdown is that although the solo proprietors (farmers) decrease, the incorporated proprietors who engage in agriculture increase. It is said that the increase of the one's place of agricultural work as a "salaried worker" is one of the factors in which the number of new young farmers has been increasing. Furthermore, there are recently so many support systems by the Japanese Government in enjoying in agriculture, and the various efforts toward the environmental improvement for young farmers have been made. It is thought that these points have been connected with the increase of the new young farmers [6].

If the flow of "incorporation of agriculture" progresses even further in the near future, a large scale agricultural management groups that are incorporated (company corporation etc.) will have been established. And the emphasis on agriculture leads directly to the importance on "water" consequently. Furthermore, the machine utilization rate also increases with the increasing of the incorporation of agriculture. It is said that the act of incorporating an agronomy is valid in terms of both increased size of agriculture and the securing of successors At present, Japanese government sets a national goal of around 50,000 people at 2023 [cf. around 14,000 (2011), around 23,000 (2017)] to increase the number of incorporation of agriculture [7].

Referring to the coronavirus (COVID-19), a prominent world-renowned biologist Prof. S. Fukuoka states that "the behavior of the virus is an altruistic existence rather than a selfish one which reproduces oneself [Intent]" [8]. As he so aptly stated, we should regard the virus as an altruistic one, and it is necessary for us to have a courage with which we proceed further the flow of incorporating an agronomy as mentioned above. When thinking about these problems, it is thought that the practice of the thought, i.e., "Small Is Beautiful: Economics As If People Mattered [1973]" proposed by Ernst F. Schumacher (Worldwide fam- 
ous British economist) will be very important [9]. In reference to water supply, it is thought that the idea, i.e., the construction of the self-disciplined (self-sustaining) water supply system at each household and a handful of residences will be very important. This is a shift in one's way of thinking from "Water Supply with Long Pipe" to "Water Supply with no Pipe/Short Pipe". If we could make it with "Self-Help" as the starting-point in the form of "Mutual-Help (agent of operation and maintenance [a round, maintenance, water quality check etc.] by the supports of 'e.g. Crowd-Rehiring' named after crowdfunding)" and "Public-Help (support by the administration [subsidy etc.])", the sustainability will be also ensured further. In other words, "Self-Help" (It means to enrich oneself by wisdom of one's own initiative spontaneity. Compared "Self-Help" to a water treatment, it may be "Self-Purification") "to build a trusting relationship [fate of good choice] in the human society [various fates] is absolutely basic principle". And "Mutual-Help" doesn't exist without "Self-Help". And further "Public-Help" is not anything like both "Self-Help" and "Mutual-Help". That is, it should be understood that in order of "Help" "Self-Help" $\rightarrow$ "Mutual-Help" $\rightarrow$ "Public-Help" is fundamentally important.

In exploring an autonomous independent water supply system, authors have realized the importance of the sustainable water supply utilizing regional features in isolated islands. This paper is further study from the previous one [10]. This time we have narrowed down the mixing rate of mixed water. In this study, the mixed water less than $0.74 \%$ (blood concentration) has been prepared first, and then divided it into five kinds of the mixing rate of mixed water. And we have compared and examined the characteristics of the mixed water from the viewpoint of the relationship between salinity and $\mathrm{pH}, \mathrm{ORP}$ and that of Dissolved Hydrogen, and examined the possibility of mixed water as a drinking water.

\section{Importance of Unlearning}

\subsection{Metathinking Ability of Unlearning Which Is Needed in Post-Corona Society}

In the process of the end to the Coronavirus (COVID-19) pandemic, the idea on the unprecedented new initiatives is exactly the same with both "agriculture" and "Economy". Once, a British economist Adam Smith (The father of modern economics, Philosopher, Ethicist, 1723-1790) has advocated the physiocracy. Its very essence is a spirit (will), i.e., living by the sweat of one's brow, doing all one can do, sharing the one's joy of cooperation. It means that the "agriculture" could evolve into the "industry" by only after having the fulfilling of the spirit. An organization called a corporation is also exactly the same. The organization is not formed from the beginning. At the beginning, it is just a group. We call it "unincorporated association", and a power relationship in a group is formed by the structure of "a peer group of comforts". After that, the group is gradually growing, and the increase of the number of the group is created. In the process of the increase of the numbers, the several walls (10-people barrier $\rightarrow 30$-people 
barrier $\rightarrow$ 50-people barrier) appear to block the enlargement on it in each case. However, by the blocking, the chemical reaction occurs in the groups for the first time. There, various values, rules, regulations etc. are set, and eventually the formation (building) of the organization begins by the starting of the self-discipline and autonomy. It is thought that the way of metathinking of unlearning is here needed for post-corona future society. We return to the basics and create a new social value with a new framework “晴耕雨読 in Japanese” (It means “on a fine day (晴), work in the field (耕), and on a rainy day (雨), read books (読)”. In short, we should create a living quietly and comfortably free from worldly cares), but the present system of "agricultural corporation" It is thought that a business in which erstwhile values driven management is firmly respected is necessary and important. We think that in the corona crisis, an action that we avoid this population concentration to the metropolis such as Tokyo and Osaka in Japan and make a rich and wealthy society in the countryside one of true SDGs is the most important.

\subsection{Unlearning the Balance; Equilibrium}

We often hear the word "Balance/Equilibrium." By the way, we here consider the meaning of keeping a balance in water supply issue. Prof. S. Fukuoka (Biologist as mentioned above) has also published a lot of books on the Dynamic Equilibrium (a state in existence by balancing totally) [8]. Authors have introduced his way of thinking in previous paper (JWARP, 2018). According to him, this word (Dynamic Equilibrium) is based on the word "Dynamic State" which was advocated by Rudolph Schoenheimer about 90 years ago [1930s]. He is an American biochemist (1898-1941), and is said one of the greatest life scientists in the $20^{\text {th }}$ century. By using the Schoenheimer's discovery, Prof. Fukuoka states what the meaning of the continuation of eating is and how life is maintained showing the issue of Bovine Spongiform Encephalopathy: BSE) [11].

Prof. Fukuoka says as follows in this book. "Physics has taught us what we can do and also at the same time what we cannot do as a matter of fact. "An extra workload is needed to accelerate something, and further energy has been lost somewhere in the environment. On the other hand, the efficiency is a negentropy which has appeared by the acceleration, and we have to pay one's tab somewhere in the environment (Simple principle: The Law of Energy and Entropy). That is, both animals and human beings are components of the environment and are in a dynamic equilibrium relationship. Therefore, if a part of the relationship is disturbed by artificial forces (i.e., recombination and acceleration) we are absolutely subject to the influence of a restoration (swinging back). The scourge of disease we are now suffering is none other than a retaliatory action from the environment. Because life and the environment have been connected at a fundamental level by the flow of molecules-[omit] - Prof. Schoenheimer has revealed that the dance of the molecule such as a "Pas de deux (Ballet vs Dance)" is conducted constantly between living things (e.g., human beings) and the envi- 
ronment, and has also succeeded in describing it while keeping a high-resolution of molecular level for the first time in the world. Only around 60 years have passed since the Copernican revolution, in a sense, in the view of nature was done by him. Omit-It is necessary for us (who are always confused over environmental issues) to re-evaluate his work, and to replace the view of life of "flow" as an old and new axis of coordinates. [Intent] Then Prof. S. Fukuoka has further extended the concept of Schoenheimer's Dynamic Equilibrium, and redefined that "the life was a 'flow' in dynamic equilibrium". This is a proposal of the new view of life by him [12].

Here, he shows risks that matters are decided by looking at just only a certain part of it especially through the example of mad cow disease. He says that the whole picture is lost in this way of thinking. That is, this is an indication that we cause the misunderstanding by the logic of partial thinking. The life phenomena of the 3.8 thousand million years on earth are incessant flow, and all the phenomena are connected to one another. That is, it means that the order is kept by the complementation (general circulation). Therefore, Prof. S. Fukuoka does mention that just the "restoration of equilibrium (balance)" is an important viewpoint in the century of the environment. Based on such a view of life, it will be pointed out that the meaning of the word, i.e., equilibrium (balance) has been unlearned deeply so far in the world including Japan. This means that regarding the "water" and "salinity", this system was placed on the center. That is, a way of indicating "solvent" in the solution and concentration notation by "solute" in describing the object showing the feature was used. We think as follows. It means that the theory of "dynamic equilibrium (view of dynamic biochemistry and electrolyte (ion) balance)" has lacked in the approach so far.

\subsection{Unlearning the Drinking Water}

We think that the unlearning for the drinking water is also very important and here try to unlearn the drinking water from the viewpoint of both 1) self-directed (self-stood) \& dispersion and 2) creation of the new job.

First, regarding 1) this is an issue of management. As we pointed out in a previous paper [JWARP (2018)] [13], it is difficult (impossible after all) to balance "economics" with "the environment". It is clear that we reach the cost (money) issue in the end if we look back on the history (Ex. Japanese ecologist, Prof. Y. Kurihara (1926-2006)) discourse: "Yugen no Seitaigaku (Finite Ecology)", 1975, in Japanese [14]. Incidentally, we can see throughout this book how stable steady state is supported by the common coexistence mechanism in a different world such as nature inside the flask, world in bovine stomach and space-base story. It will really cost to balance "economics" with "the environment", including luxury. Therefore, we could say that it is very important to have a strong will (resilience) in order to keep "economics" and "the environment" balanced in some way without spending too much cost. By the way, there are two intellectual forms having different roles, that is, "Scientia [Latin]" and "Sophia [Latin]". 
Therefore, while taking the "Scientia" so far into consideration, to display the "Sophia" fully and creatively (i.e., from "Scientia [Logocentrism]" to "Sophia [ Physis-centrism]") will be required in the water environmental field from now on.

Under such a corona disaster circumstance, it goes without saying that if just only self-restraint economic activity with no financial support is required, the econo mics will become useless (diseases). "Water" is essential for the human life more than "money". Regarding the "money" as a media on the economics, "cashless" has at present become quite common. Then, if one does not have money one can live one's life. Needless to say, it is actually difficult for one's life to live without money unless a little complicated economical system was changed. However, we cannot live without "waterless" indeed. Therefore, we have to regain the society in which everybody can secure drinking water anywhere anytime.

Although the conservation of environmental is a matter requiring immediate attention for that, the nature has been destroyed by human beings. Under such a destroyed environment we cannot dig a well and get water. Even if we are now said to use the well-water", we do not know where the suitable place of the well is. In this situation, we are apt to think a suitable management way to dig well-water, and carry out it utilizing the same economic system, i.e, the range of market economy. With this sort of way, we are just stuck in the situation in which we do learn the market economy again. The unlearning for the drinking water means that we do not pursue the effectiveness and efficiency in the framework of the market economy. They do not matter. That is, the marketing area named after the marketability is not necessary there. In this case, we think that the world of "non-marketing" is needed. The implication of the dispersion here is also not just a risk aversion. It means to enjoy what one can do without thinking about the risk in much detail. Although seeking the economic independence in the region by using eco-money was popular once, it is thought that this is also "unlearning" in current currency in a sense [13]. Regarding 2) creation of the new job, we should lay the "groundwork" to strengthen one's senses of "mutual help" in the society in which jobs are not created with company's social contribution as before. That is, we think that it is necessary for us to create, so to speak, a "crowd-hiring" like a "crowdfunding" which is starting to spread in the world of finance. The fundamentals of investment here are not the conditions for growth (necessary condition) as ever. It is important to investigate the creation of a positive atmosphere (sufficient condition) for loving (enjoying) the human life greatly. We think that this is an "unlearning" for the drinking water.

\subsection{Unlearning the Mixed Water as a Drinking Water Source}

We here examine the possibility of the mixed water as a drinking water source from three separate points of view.

First of all, the reason why the seawater and the rainwater have not been posi- 
tively regarded as being permitted as drinking water sources, and secondly, the reason why the recognition of the importance of the mineral balance of the seawater in Japan has been low awareness so far, and finally, regarding the evaluation of the water quality of the mixed water, we examine to unlearn the significance of evaluation viewed from the electrolytic concentration $(\mathrm{mEq} / \mathrm{L})$ on the basics of evaluating the concentration evaluation method $(\mathrm{mg} / \mathrm{L})$ so far respectively.

At the beginning, the reason why the seawater has not been positively regarded as being permitted as a drinking water source may be grouped together in the following three points. The first point is the problem of the salinity concentration. In general, it is said that the salinity concentration of the seawater is around $3.5 \%$ and that of fluids in human body is around $0.9 \%$. Therefore, drinking the seawater has caused some risks for health such as dehydration etc. The dehydration is the collapse of balance of the osmotic pressure between the intracellular fluid and the extracellular one. It is fundamentally developed by "seawater", but even in case of the excessive drink of the "fresh water" it is developed, too.

Regarding the "sea water", the human body emits the extra salinity as a urine which is formed in the kidneys through a blood. Therefore, the salinity concentration is kept constant. The concentration of seawater is higher than that of the body fluids. If one drinks the seawater, the salinity in the body increases. Therefore, the body needs to take water further to revert (dilute) it back. If one drinks it more, it will increase further, and an infinite loop will be formed one after another. Furthermore, the osmotic pressure increases with increase of the salinity in the extracellular, and the water which has been kept in the intracellular with high salinity goes to the extracellular more and more. Accordingly, as the cellulars cause the dehydration and are unable to transport the oxygen etc., various kinds of function of the body goes down. As a result, a fear that one could lead to death may happen.

On the other hand, regarding the "fresh water", the sodium $(\mathrm{Na})$ is lost by a large amount of sweat that come out of exercise etc. If one persists in the exercise, the sodium chloride $(\mathrm{NaCl})$ in the sweat would be weaker after a predetermined time elapses. As the water has naturally been lost, a brain command named "water-intake" is sent. This is a signal with which one's throat feels dry. However, if one drinks just the fresh water at that time, just only the water without sodium $(\mathrm{Na})$ is replenished. It means that sodium $(\mathrm{Na})$ is not replenished. Then body fluid is diluted by that water, and the body will become unable to move by repeating that. Because of this, there is no improvement in symptoms of dehydration if one drinks the fresh water at the heatstroke. That is because the salinity in the body is diluted by drinking fresh water and the dehydration of the intracellular fluid progresses by contrast. It is in general said that no matter how much one drinks the fresh water under the dehydration, it is difficult to improve the dehydration rate by much more than $50 \%$ against that.

The second point is bacterial problems such as Vibrio vulnificus $\left(V_{V}\right.$. etc. A 
bacteria named $V_{v}$. is in the sea water of the coast in the summer season. It is said that if those who have basic diseases (liver disease, immune deficiency, anemia etc.) are contaminated with the bacteria through the seafood, they have severe symptoms. And it is also known that there is an infection through a wound on one's hands and feet. It is said that if $\mathrm{Vv}$. got in one's blood and one is infected with it, the fatality rate is $50 \%-70 \%$, and that it seems to be a bit high value, i.e., a terrible infection [15].

And the third point is environmental hormones (endocrine disruptors) such as BPA etc. The environmental hormones are chemical substances with the hormone action which disrupts the endocrine system of a living body. US environmental activist Dr. Theo Colborn (1927-2014, Blue Planet Prize award in Japan) et al. published a book entitled "Our Stolen Future: Are We Threatening Our Fertility, Intelligence and Survival?" in 1996, and posed the problems with environmental hormones. It attracted worldwide attention. They point out that the chemical substances existing in the environment disrupt the hormone action. Therefore, they have a possibility of both the inhibition of reproductive functions and the causes for malignant tumors. The Environment Agency at the time in 1998 listed up 67 kinds of chemicals (Dioxins, PCB, DDT, nonylphenol, BPA, Phthalates etc.) as suspected substances of environmental hormones. And it is regarded that about one-half of those were pesticides [16].

The reason why the recognition of the importance of the mineral balance of the seawater in Japan has been low awareness so far may be grouped together in the following three points. The first point is a scientific perspective. Regarding this. The theory (so-called "salinity = hypertension") by two doctors (Dr. Luis Daul (1954, USA), Dr. Menellie (1972, USA) is accepted.

Dr. E. Kuma (Physiology) makes the following comment for both doctors' paper [17]. The result of Dr. Daul's study in Japan is briefly as follows. He studied the relationship between the amount of the salt and the number of patients with high blood pressure. As a result, it turns out that the amount of salt intake and the number of patients in the Tohoku district was two times in comparison with the Kyushu one. The contraction of blood vessels and the increase of blood pressure are natural phenomena. Because the Tohoku district is even colder than the Kyushu one. To conclude that the salt is the cause seems to be lacking in sufficient explanation. As mentioned above, it can be said that the theory (so-called "salinity = hypertension") is based on the weak basis. While, the point of Dr. Menellie's study is as follows. He had fed 10 mice 20 times the normal salt and $1 \%$ salt solution. As a result, 4 mice had high blood pressure six months later. Feeding a lot of salt to a mouse, it makes him thirsty. He added salt to the drinking water for the mice in this experiment. Under such an addition of the extreme salt and some stresses, it is not strange that one has not only high blood pressure but also other diseases. Nevertheless, the case in which 6 mice did not have the high blood pressure has, or rather, been worthy of remark. (Intent)

When published first, the scientists in Japan and the US objected (refuted) to 
the theory as an incomplete hypothesis scientifically. The late Medical Dr. K. Aoki (a world authority on research in Hypertension), former prof. of faculty of medicine, Nagoya City University Japan, has published an opposed paper regarding this in 1972. Prof. Aoki observed the experiment grouping the mice into four groups (1) high salt diet + salt solution (1\% in concentration), (2) high salt diet + fresh water, (3) ordinary diet + fresh water, (4) low salt diet + fresh water). As a result, it turned out that just only group (1) has a high blood pressure, and the other 3 groups ((2), (3) and (4)) did have no change on blood pressure. Therefore, he has come to a conclusion that the amount of intake of the salt has nothing to do with blood pressure. And he says that the belief with a reduced salt content produces a new disease named "Salt-free disease" [18]. That is, he is drastically opposed to the fixed concept with which salt is the cause of high blood pressure. Furthermore, he has stated the following perspective in his book. [19] "Human beings are animals that were born from the sea. The components of the blood are surprisingly similar to those of the seawater. That is, it can be said that the human beings are also salted living things (1\% in concentration). Therefore, it is impossible for them to live without salt". (Intent)

And in 1983, an American Medical Dr. John Ralph makes the following comment for both doctors' paper. In the Journal of the American Medical Association named HEALTH, he says under the title 'Salt is not a poison' that "The act of forcing the ordinary people to do any salt reduction was no scientific basis, and its efforts were of no avail, too. The act of reducing the salt in food production was meaningless." (Intent) [20] However, the discussion connecting the salt with high blood pressure (i.e., a way of thinking by American researcher and the verification) was epoch-making when published first. Therefore, it appears that the two American Doctors' result mentioned above spreads quickly all over the world, and has been believed in the world.

The second point is a legal perspective. The $4^{\text {th }}$ salt industry control by the government can be considered as an example of a legal perspective for this in Japan. In 1971, "Act on Temporary Measures on the arrangement of the salt industry and promotion of modernization" was promulgated. And In 1972, the government (Japanese Monopoly Corporation) abolished all the salt farms which were distributed at 26 places in all parts of Japan at that time. In place of that, the salt industry company using the seawater concentration device, i.e., "ion-exchange membrane method" which is a way of producing the highly pure refined salt (sodium chloride: $\geq 99 \%$ ) was summarized in seven places in Japan. [21] Speaking of "1972", it is just in the year that Dr. Menellie presented the theory as mentioned above.

The third point is a technical perspective. The immature measurement technology which analyzes the trace constituents such as ultra-trace, super-trace and extremely-trace can be considered as an example of a technical perspective for this in Japan. It is said that around 85 kinds of minerals exist in the seawater. It can be pointed out that the measurement technology to analyze the values of 
those constituents (e.g., $\mathrm{mg} / \mathrm{L}\left[10^{-3} \mathrm{~g} / \mathrm{L}\right] \rightarrow \mu \mathrm{g} / \mathrm{L}\left[10^{-6} \mathrm{~g} / \mathrm{L}\right] \rightarrow \mathrm{n} \mathrm{g} / \mathrm{L}\left[10^{-9} \mathrm{~g} / \mathrm{L}\right] \rightarrow \mathrm{p}$ $\mathrm{g} / \mathrm{L}\left[10^{-12} \mathrm{~g} / \mathrm{L}\right] \rightarrow \mathrm{f} \mathrm{g} / \mathrm{L}\left[10^{-15} \mathrm{~g} / \mathrm{L}\right] \rightarrow \mathrm{a} \mathrm{g} / \mathrm{L}\left[10^{-18} \mathrm{~g} / \mathrm{L}\right] \rightarrow \mathrm{z} g / \mathrm{L}\left[10^{-21} \mathrm{~g} / \mathrm{L}\right] \rightarrow \mathrm{y} \mathrm{g} / \mathrm{L}$ $\left.\left[10^{-24} \mathrm{~g} / \mathrm{L}\right]\right)$ was immature in 1970s. It even now appears that all the minerals, especially extremely-trace one has not been measured. Looking at it from another perspective, it can be said that the super-trace and extremely-trace, if anything, occupies almost all the parts quantitatively. "Action (function)" is decided depending on the framework. It is difficult to estimate the framework of the function from itself (one constituent). Because the function means the relationship with other constituents. As one already knows, the values of ultra-trace and super-trace $(\mu \mathrm{g} / \mathrm{L}, \mathrm{ng} / \mathrm{L}, \mathrm{pg} / \mathrm{L}$ ) have various kinds of bad influences on one's generative function etc. Incidentally, the year in which the environmental hormones were getting to be recognized to the world was 1996-2001 [22].

On the other hand, the reason why the rainwater has not been positively regarded as being permitted as a drinking water source may be grouped together in the following three points. The first point is the problem of air pollutants $\left(\mathrm{NO}_{2}^{-} \& \mathrm{NO}_{3}^{-}\right)$, the second one is the bacterial problems such as general bacteria and colitis germ etc. And the third one is that of dust and organic matters.

Then, if we can solve the 6 points (seawater: 3, rainwater: 3 ) mentioned above, will it be possible to drink the mixed water as a drinking water? Here we take the possibility of drinking water into consideration. The fundamental approaches (3 points) in seawater are as follows. 1) "Filtering process" by a suitable (advanced) household water purifier, 2) "Dilution process" and 3) "Sterilization process" by exposing it to the acids (chlorine, chloric acid, gastric acid equivalent etc.). While, the rainwater approaches (3 points) are as follows. 1) "Filtering process" by a suitable (standard) household water purifier, 2) "Reducing process such as nitrate nitrogen etc." and 3) "Sterilization process" by exposing it to the acids (chlorine, chloric acid, gastric acid equivalent etc.). Summarizing the above, it is understood that the basic water treatment to drink the mixed water as a drinking water was eventually based on a combination of these three points, i.e., "filtering process", "reducing process" and "exposing process (sterilization)".

Therefore, we carried out the experiment being conscious of the three points as a whole. In particular, we first conduct the act of removing dust and organic matters etc. as "filtering process", second the act of mixing the rainwater with seawater as "reducing process" and third the use of citric acid (food additives) and $\mathrm{pH}$-reducing-agent (ingredients: sulfuric acid/hydrochloric acid) as "exposing process (sterilization)". Incidentally, the sulfuric acid of the value of $20 \mathrm{mg} / \mathrm{L}$ as an upper limit has been used in the actual purification plant, and the other, hydrochloric acid exists in the form of $\mathrm{H}^{+}$and $\mathrm{Cl}^{-}$in the water. This agent reduces the $\mathrm{pH}$ by decreasing the carbonate hardness which shows the amount of $\mathrm{Ca}$ ion and the $\mathrm{Mg}$ ion dissolved in water. Through these processes, we attempt a formation of hydrogen-rich water adding the $\mathrm{Mg}$ with a bicarbonate of soda (food additives). That is, when putting the $\mathrm{Mg}$ with the mixed water, the reaction between the Mg and the mixed water occurs. As a result, the dissolved hy- 
drogen $(\mathrm{DH})$ is generated. Here we use this water containing the $\mathrm{DH}$ (so-called, hydrogen water) as a drinking water. Judging from the water quality items which are taken up at this stage, it is thought that the possibility of mixed water as a drinking water will be high.

Summarizing the above, it can be said as follows. The possibility of the mixed water as a drinking water can be increased by mixing the rainwater centering on the "filtering process" with seawater centering on the "dilution process $(\leq 0.9 \%)$ " based on the "exposing process (sterilization)" under highly acidic condition like gastric acid ( $\mathrm{pH} 1$ - 2).

By the way, it will be important for us to think about the balance (ratio) of the solutions ( $\mathrm{Na}, \mathrm{K}, \mathrm{Ca}, \mathrm{Mg}$ etc.) in solvents, if we use the mixed water as a drinking water on the water quality evaluation. In that case, the mineral balance of the "seawater" would serve as one of the useful references. To put it very simply, it follows that one can drink the mixed water diluted $(\leq 0.9 \%)$ after clearing the water quality criteria. At present, it is said that there are three kinds of minerals such as essential minerals (29 kinds), main minerals (7 kinds) and trace minerals (70 kinds), and those are needed to keep one's health. It is said that the minerals perform a valuable work for maintaining/improving one's life and health. The trace minerals include a mercury $(\mathrm{Hg})$ which became famous for Minamata decease (Japan, 1950s, $\geq 25 \mathrm{mg} / \mathrm{L}$ ) and a cadmium (Cd), famous for Itai-itai disease (Japan, 1910s-1960s, $\leq 0.9 \mathrm{mg} / \mathrm{L}-\geq 3.0 \mathrm{mg} / \mathrm{L}$ ). However, the values of the background level in the natural world on both $\mathrm{Hg}$ and $\mathrm{Cd}$ are originally $0-0.000006$ $\mathrm{mg} / \mathrm{L}$ [Criteria: $\leq 0.0005 \mathrm{mg} / \mathrm{L}(\mathrm{Hg})$ ], and $0-0.000002 \mathrm{mg} / \mathrm{L}$ [Criteria: $\leq 0.003$ $\mathrm{mg} / \mathrm{L}(\mathrm{Cd})$, respectively. These values are capable of sufficiently clearing the environmental standards [22].

It is in general said that as the $\mathrm{Hg}$ exists in nature and the amount is a very small one, it does not cause the obstacles to the people. That is, it can be said that when it comes to the two major pollution-caused illnesses, it was discharged into the sea by the person. So-called, they are man-made disasters. Incidentally, the observed value of " $\mathrm{Hg}$ " measured in ocean area near Japan in 2019 was 0 $0.000016 \mathrm{mg} / \mathrm{L}$ (around $1 / 30$ of environmental standard), and that of "Cd" was 0 - $0.000082 \mathrm{mg} / \mathrm{L}$ (around 1/40 of that), respectively [23]. And, regarding the sterilization (including the correspondence to COVID-19), it is considered that the fungi die out by exposing the strong acid (e.g., gastric acid level, pH: 1 - 2) for around 1 hour [24]. Furthermore, we consider that dust and organic matters can be cleared by "filtering process" using the suitable household water purifier. In short, it means that they can be cleared by setting up the suitable water purifier. All that is left is to check the water quality in detail using the checker (general check/ bioassay) at each home when drinking it, and it will be important that one finds the optimum situation while always referring to the WHO standard value (including the proposal). That is, it means that one always checks the water quality while monitoring the pollution level by the purifier. And if the result is good, leave it as it is, if bad, respond promptly. Through such repetitive feed- 
back, the value of the best water quality is always secured. Through a common experience, one acquires a habit of taking the change of water quality personally. We think that this habit exactly leads to the spirit saying "Think Globally, Act Locally" [25], and that it directly links to one's actions with which we can seriously protect both the ocean and the atmosphere. That is, strong incentive which means that the act of polluting them directly results in polluting one's own life is given to the user. We think that it is possible to build a high resilience system (self-help $\rightarrow$ mutual-help $\rightarrow$ public-help) in the region through this incentive. However, as can be seen in corona disaster, the issue of prioritization due to triage will be inevitable as an actual problem in the stage of public-help. We can understand that issue, but everyone is precious and irreplaceable existence. That is, it must be remembered that it is most important point for us to have the perspective saying "Human life is the supreme value" when one think about the limitation of triage. Now under corona situation is the time to require the perspective saying "No one will be left behind" stated as the basic principle of SDGs.

By the way, body fluids (water component) are maintained in a certain mineral balance by the action of homeostasis. It is said that although body fluids (water component), mineral nutrition (basic of the fluids balance), mineral (metabolic factors of the three major nutrients) and vitamin nutrition are in very trace amounts respectively, they play significant roles more than three major nutrients(proteins, lipids and glucides). It is said that although 85 kinds of the mineral compositions in the seawater have been discovered so far, the distribution of mineral concentrations and the mineral balance in one's body fluids (serum) have positive correlation. Therefore, it is said that human's amniotic fluid would be the seawater after all. Humankind have lived on the mother's amniotic fluid (water) just before birth, and one comes out from the fluid (water) for the very first time in one's life. It is thought that the origin of cells exists in the seawater and the seawater has been gradually concentrated up to the higher percentage (around 4 times of the serum: $0.9 \% \times 4=3.6 \%$ ) than the bodily fluid and that as it has been hard for living things to live in the seawater, they had moved onto the land with both the gills and the lungs [26].

From this kind of circumstance we think that based on the concentration evaluating method $(\mathrm{mg} / \mathrm{L})$ so far is also significant on the water quality evaluation of the mixed water.

\subsection{Unlearning the Damage Caused by Seawater Invasion}

In an electrical sector, an agricultural sector including a public works sector etc., a word saying "salt damage" due to sodium chloride $(\mathrm{NaCl})$ certainly exists. In a public works sector, for example, the deterioration of strength due to the rust of a reinforcing rod of the reinforced concrete structure at the coastal regions occurs. And in an electrical sector, if the salt water at the coastal region touches the wire, the considerable electric current flows. Even just only rainwater, as it has some impurities, the electric current flows slightly. Therefore, a short circuit oc- 
curs, and that will cause the fire etc. As a result, one has no choice but to stop the electric power transmission. Furthermore, in an agricultural sector, there is a damage which is called "the chlorination of farmland (soil)". That is, if seawater percolates through the groundwater level, the water is chlorinated even at the inland areas which are the place far from the coastline. In addition, it is also said that when the soil has been covered with seawater once due to the flooding and high wave etc., the farming will never be able to be done it again. When an author visited Melbourne, Australia in 2014, he has heard the damage from the researchers in water resources being reported that the persons concerned have cut trees $(\geq 70 \mathrm{~m}$ ) called "eucalypt" down to reclaim the new farmland, but after that, got damaged by the salt [27].

Here, we make sure of the mechanism i.e., how the plants draw the water and nutrients from the soil regarding the damage which is called "the chlorination of farmland (soil)" [28]. The mechanism is as follows. The $80 \%-90 \%$ of weight of a plant is occupied by water. And the plants draw the water and nutrients from the soil through those roots. The roots extend in a branched state, and increase the surface area which is in contact with the soil. This is because the roots draw the water and nutrients from the soil efficiently.

Regarding the roots, the one which extends from the neck of the root on the ground is called "main root", and the one, in a branched state, "side root", and the fine fibrous root which occurs ahead of there, "root hair". The third one into which it is easy for the water to flow is "root hair". This can capture a lot of substances such as sugars, $\mathrm{Na}, \mathrm{K}$ etc. into the cell, because the osmotic pressure becomes higher than that of soil. The cells of the plants which are wrapped in a semi-permeability membrane are filled with the liquid called cell sap. The membrane has characteristics that it can pass the water but cannot pass the other substances dissolved in water. The osmotic pressure works on both the outside and the inside of the cell separated by the membrane. If the concentration of the cell sap is higher than the outside, the water which exists outside the cell is absorbed and vice versa. That is, if lower, the water, to the outside. In plants, the osmotic pressure of the inside becomes higher than that of the outside. And the water absorbed by the root hair is moved to the conduit of the inside of the roots due to the osmotic pressure difference. Incidentally, there are dedicated waterways which carry the water called conduit in the inside of the plants. Through this conduit, the water is sent to every corner of the plants. The power to absorb the water using the difference in osmotic pressure works as a power pushing up the water from roots to the ground. This phenomenon is called "root pressure". It is said that the measured value of this pressure is $0.1-0.3 \mathrm{MPa}$ in many plants. That is, "roots" have the power which pushes up the column of the water up to $10-30 \mathrm{~m}$. However, it is impossible for only the force of root pressure to push up the water against gravity up to more than $70 \mathrm{~m}$ (tip of the tree). The main power to take up the water is a phenomenon of the evaporation of the water caused by opening the pores of the leaves, namely, "transpiration." When the 
water content of the leaves is lost by that, the cell sap concentration of those becomes higher than that of the trunk and branches of the tree. Therefore, the osmotic pressure works to try to lower the concentration, and the water is pulled up from the trunk and branches of the tree. On fine days when transpiration is active, it is measured that the suction force of the water at the base of the leaf of even a plant about $1 \mathrm{~m}$ high exposed to the direct light is around $1 \mathrm{MPa}$. Furthermore, it is said that the plants which live in drought have the suction force of more than 1.5 $\mathrm{MPa}$. The roots push up the water by the root pressure, and the suction force has changed it to one water column connecting the water from the roots to the stems and leaves by the transpiration. The molecules of water have a characteristic that the electrostatic attraction works among molecules, and they are attracted to each other. This force is called "cohesion". Even a high tree in the conduit from the roots to the top of the tree, the column of the water connects without including any air-bubbles, and the suction can be done due to the strong cohesion of the water and the wall of conduit which has a composition very easy to fit with the water. It is understood from the above that the three processes ((1) "roots pressure" $\rightarrow(2)$ "transpiration" $\rightarrow$ (3) "cohesion") are very important in the mechanism in which the plants draw water and nutrients from the soil.

The mechanism with which trees (eucalyptus) suck up the water was confirmed by taking what was mentioned above into the consideration. Therefore, it means that the act of cutting the trees called eucalyptus to expand the new farmland has left the water (Nourishment containing salt water) which has been sucked up so far on one's farmland. Based on the reason mentioned above, we could say that the "salt damage" has been brought about to the new farmland in Melbourne, Australia. By the way, the author remembers that a topic regarding the genetically-modified crop had been discussed as one of the countermeasures at that time [27].

As seen above, it is thought that the seawater has had, if anything, the strong negative image as a "harmfulness" for the general public, what's more, the people who work in specialized fields so far.

So maybe that's why, the water from which the salt $(\mathrm{NaCl})$ was removed using mainly the "desalination device" was the mainstream for agricultural water. However, the "Desalination of seawater" to make the fresh water costs quite a bit of money, and the energy consumption is also too high. Therefore, this desalination has a lot of parts that are incompatible with the direction of SDGs of the United Nations.

On the other hand, the approach with which it is possible to grow the crops even in the seawater has become active in the last few years in the world. The countries such as Netherlands (Salt Farm Texel), Scotland (Seawater Solutions), China, Pakistan, Bangladesh, Kenya and so on trying out the "reverse thinking" exist at present in the world. It seems that the possibilities of seawater farming will expand more and more toward both the increase of food production on a 
sustainable basis and the achievement of the SDGs [29].

By the way, Prof. of Kyushu Univ. M. Kitano (agricultural meteorology) has presented a paper entitled "nougyou ni okeru Shio no Riyou-Oishii Yasai zukuri (A utilization of salt in agriculture-Growing delicious vegetables)" in 2007. According to the paper, it is said that the seawater has been utilized for improving the quality of the crops since ancient times in Japan. He introduces here a lot of examples of utilization (agricultural techniques) in Japan [30]. According to this literature, it is said that the people have utilized the "seawater" and "seaweed" as a nearby resource in agriculture from the Edo period in Japan that is surrounded by the sea. Some examples of the utilization are briefly described as follows.

1) Long onion: To spread 10-fold diluted solution of seawater $\rightarrow$ In crease of iron, carotene etc.

2) Cabbage: To spread 50-fold solution (late after noon) \& 100-fold solution (afternoon) $\rightarrow$ Increase of sugar content, Decrease of nitrate nitrogen etc.

3) Corn-field: To put sea water (20\%) into fertilizer $\rightarrow$ Increase in effectiveness.

4) Seaweed: To spread it $\rightarrow$ Works for all crops.

5) Mandarin orange: To spread seawater at root of tree in the middle of Winter $\rightarrow$ Good growth.

The essential elements which are important for the growth of plants have been also mentioned in the part of mineral component of seawater. It is said that "Sodium (Na)" which is the most numerous in the seawater is not the essential element singly for the growth of plants, but an agronomic useful elements in relation to "Potassium (K)". And " $\mathrm{K}$ " is an "abundance essential element" singly, and "Chlorine" which is also contained the most as an anion is a "microdose essential element" singly. Furthermore, the three kinds of water styles ((1) surface sea water, (2) deep-sea water, (3) bittern water [main component: $\mathrm{MgCl}_{2}$ ]) are introduced as seawaters which are available for the growth of a plant. All the types have utilized in the ways such as the spreading to the plants (diluted solution with suitable concentration) and the application to the soil/organic fertilizer (diluted solution etc.) aiming at growth promotion, food taste improvement and disease control etc. However, it is stated that there are two types of the crops depending on the food, i.e., one is a food with high salt tolerance, and the other, low salt one. Therefore, it is necessary to consider the dilution rate and application method etc. too. Finally, the author describes the effect of application. The three effects are (1) mineral effect, (2) chlorine effect and (3) salt stress effect.

Regarding (1), it is said that many of "abundance essential elements $\left(\mathrm{C}, \mathrm{H}, \mathrm{O}_{2}\right.$, $\mathrm{N}, \mathrm{P}, \mathrm{K}, \mathrm{Ca}, \mathrm{Mg}, \mathrm{S}$ )" and “microdose essential elements (Fe, Mn, Zn, Cu, B, Mo, $\mathrm{Cl}, \mathrm{Ni}$ )" which are needed for the growth of plants are the minerals contained in seawater.

And it is stated that it is necessary to keep in mind the "two basic principles" in the fertilization when thinking about the mineral effect. To put it simply, the two principles are as follows. 
1) Law of the least nutriment: If one of the factors needed for growth of the plants is insufficient, the growth of the plants is dominated by that one-factor even if the other factors exist sufficiently.

2) Law of diminishing returns: The lower the nutriment is, the larger the application effect of a certain nutriment becomes. And when increasing the amount of applied fertilizer, the effect on increased productivity decreases gradually.

It is also said that the reason why the cultivation methods using the seawater have not been expected to come into world-wide use as "universal farming" depends on the two principles mentioned above. Furthermore, the "Magnesium $(\mathrm{Mg})$ " which is the main component of the seawater \& bittern water activates the fixation of carbon dioxide (photosynthesis) in the chloroplast, and also serves as a suppression of the generation of active oxygen in conjunction with the central component of the chlorophyll performing the photosynthesis. Therefore, it is said that it has a mineral effect which has been the highest expectation of the application of seawater.

Regarding (2), it is said that the seawater contains the "chlorine $(\mathrm{Cl})$ " as the anion the most, and it has been recently recognized as a "microdose essential element." It is said that this $(\mathrm{Cl})$ is known as a component with three functions. They are as follows.

1) Catalytic function in some of the processes of the photosynthesis.

2) Function as an accompany ion of the potassium ions at guard cells of pores.

3) Plant growth promoting effect.

Here, the author introduces a case in which 20-fold diluted solution (application in low concentration) of the seawater was added to the standard liquid fertilizer. And an example on promoting the growth of cucumbers is shown. There, it is stated that if the salt is set a low concentration, the damage of "sodium $(\mathrm{Na})$ " excess is relieved by that and the plant growth promoting effect by "chlorine $(\mathrm{Cl})$ "appears instead.

Regarding (3), it is said that if the seawater (high concentration) is applied to the plants, the water absorption of the roots is inhibited by the "Ion stress" due to the excess of $\mathrm{Na}, \mathrm{Cl}, \mathrm{Mg}$, and further, the increase of the osmotic pressure due to the rising of the solute concentration of rhizosphere in soil etc. As a result, the "water stress" leading to the wilting and apoptosis is brought about. It is also said that these environmental stresses (salt stress) have brought about the oxidative stress due to the various kinds of reactive oxygens to the plants further. Therefore, the plants exert the defensive functions such as antioxidation and osmoregulation etc. as a strategy for survival for the salt stresses. Regarding the former (antioxidation), the reactive oxygens caused by the stress are inactivated through the enzyme (reactive oxygen inactivating enzyme) and vitamin c (ascorbic acid) etc. such as a superoxide dismutase (SOD), and through the superoxide anion $\left(\mathrm{O}_{2} \cdot-\right)$ /hydrogen peroxide $\left(\mathrm{HO}_{2}\right)$ etc. caused by the stress. And the amino acids having anti-oxidant action etc. are produced in conjunction with 
that mentioned above. On the other hand, regarding the latter (osmoregulation), the function is as follows. The plants increase the concentration of solute (osmoticum) such as glucose, amino acids, potassium ions etc. inside the cell to avoid the wilting due to the inhibition of water absorption of the roots by the water stress. It means that the plants avoid the wilting by maintaining the turgor of cells due to the penetrating inflow of the water into the cell.

It is said that the act of producing a "tomato with high sugar content" by applying the seawater having an appropriate concentration which does not occur a fatal stress disorder to the plants is publicly acknowledged as a method in agricultural field.

Based on the reasons mentioned above, it is understood that the "salt" included in the seawater is definitely "harmful (salt damage)". However, if we decrease the concentration of the salt (around 3.4\%), that is, taking the correspondence (i.e., $1 \%$ or less), the possibility of becoming harmless or having the high general usefulness will become increased. It is thought that this way of thinking is consistent with the direction in UN Sustainable Development Goals (SDGs) in terms of the use of suppressing the consumption of local resources, the increases in energy considering the costs involved in doing that.

\section{Experimental}

\subsection{Experimental Procedure}

In previous paper (JWARP, 2020) [10], we made the mixed water (Seawater + Rainwater) on 12 mixing ratio levels, and obtained the several knowledge related to a reduction of salinity $\left(\mathrm{Cl}^{-}\right)$. In this experiment, the appropriate placement on the concentration of both 1) the organic matter i.e., dietary fiber \& powder agar used as additives and 2) the salinity has arisen as an important issue.

Therefore, regarding 1), we did not decide to use the additive which is the core of organic matter. Regarding 2), we set up new five kinds of the ratios [V/V] of the mixed water ((1) 2.5:7.5/(2) $2.0: 8.0 /(3) 1.5: 8.5 /(4) 1.0: 9.0 /(5)$ $0.5: 9.5)$. All the concentration ratios are less than $0.74 \%$ (<blood concentration). And the Magnesium (Mg: granular) is added into each of the mixed waters, and the possibility of the five types of mixed water as a drinking water was examined through the formation of hydrogen water generated from the water.

\subsection{Experimental Condition}

This time, the experimental condition used in the previous paper (JWARP, 2020) [11] was basically followed. The 5 kinds of the ratio $[\mathrm{V} / \mathrm{V}]$ of the mixed water ((1) 2.5: 7.5/(2) 2.0:8.0/(3) 1.5:8.5/(4) 1.0:9.0/(5) 0.5: 9.5) was set up and used in the experiment. In this experiment, the volume of the mixed water was $100 \mathrm{ml}$. And the irradiation time was about $90 \mathrm{~min}$ at $116 \mathrm{~Hz},-48 \mathrm{dBm}$, and the temperature, $28^{\circ} \mathrm{C}$. We focus more on the "sterilization" of the mixed water in strong consciousness with/after the corona (COVID-19) as a whole. That is, the 
"sterilization" process by keeping the situation of the strong acid ( $\mathrm{pH}: 1-2)$ was first carried out in the treatment process. Therefore, the citric acid $\left(\mathrm{C}_{6} \mathrm{H}_{8} \mathrm{O}_{7}\right)$, the $\mathrm{pH}$-reducing-agent and bicarbonate of soda $\left(\mathrm{NaHCO}_{3}\right)$ as conditioning agents on adjusting the $\mathrm{pH}$ value (oxidation-reduction) were used. Finally the trial of the formation of the "hydrogen water" using the Magnesium (granular) paying close attention to the $\mathrm{pH}$ trends is performed, and the measurement of Dissolved Hydrogen (DH) was carried out.

Twenty kinds of water quality items such as $\mathrm{Mg}^{2+}, \mathrm{pH}, \mathrm{DH}$ (Dissolved Hydrogen), ORP(Oxidation-reduction Potential), Salinity, TOC, $\mathrm{NO}_{2}^{-}, \mathrm{NO}_{2}^{-}$\& $\mathrm{NO}_{3}^{-}, \mathrm{Ca}^{2+}$, the number of General Bacteria, the number of Colitics Germ Logions, the number of Vibrio vulnificus, Bisphenol $\mathrm{A}, \mathrm{Hg}, \mathrm{Cd}$, norovirus, 2019-nCoV, SARS-CoV, ERS-CoV were selected as the analytical object items of the water quality. This time, the nine kinds of water quality items such as $\mathrm{DH}$, ORP, Hg, Cd, norovirus, 2019-nCoV, SARS-CoV, MERS-CoV, Flu Virus were added anew in strong consciousness with/after the corona (COVID-19).

And like the last paper [10], the several water quality items were used as the reference values which have been published in the previous papers. And the rain water used in this experiment was sampled in Jun $14^{\text {th }}$ at home (Sakyo ward) in Kyoto city, and the seawater, in May $24^{\text {th }}$ at Awaji Island, Yura fishing port (Sumoto city) in Hyogo Pref., Japan 2020, respectively. The reason why we sampled the rainwater in Kyoto, Japan is that this area forms a natural basin. So we can sample a standard rainwater. On the other hand, the seawater in Awaji Island, Hyogo is that there is no factory nearby. So we can sample a relatively clean seawater. And the selected sample has not represented the situation of the whole population clearly. In addition, this study was carried out in July, 2020, in Kyoto, Japan.

\subsection{Analytical Method of Water Quality}

The way of our previous paper (JWARP, 2020) [10] is basically followed regarding the basic things on the water quality. In addition, this time TOC,Vv. and BPA were used as estimated values. Furthermore, the seven items such as $\mathrm{Hg}, \mathrm{Cd}$ and five items on the virus (norovirus, 2019-nCoV, SARS-CoV, MERS-CoV, Flu Virus) out of the new nine items were also used as estimated values.

\section{Results and Discussions}

Table 1 shows the result of Dissolved Hydrogen[DH]based on the ratio of the mixed water, and Table 2 shows an example (Ratio of the Mixed Water $\rightarrow$ 1:9)/Salinity $\left(\mathrm{Cl}^{-}\right) \rightarrow 1600 \mathrm{mg} / \mathrm{L}$ ) of the analytical results of the water qualities including the estimated values. The salt intake criteria in Japan are $9 \mathrm{~g} /$ day (male), $7.5 \mathrm{~g} /$ day (female) [Average: $8.3 \mathrm{~g} /$ day]. Considering the salt intake by the ratio (1:9) of the mixed water, it becomes $5.5 \mathrm{~g} / \mathrm{L}-8.3 \mathrm{~g} / 1.5 \mathrm{~L}$. Therefore, assuming that the person drinks the water of $1 \mathrm{~L}-1.5 \mathrm{~L} /$ day, the standard value (average) can be cleared. 
Table 1. Change of $\mathrm{pH}$ and Dissolved Hydrogen generated at salt concentration in each mixed water.

\begin{tabular}{|c|c|c|c|c|c|c|c|}
\hline \multicolumn{6}{|c|}{ Mixed Water $(100 \mathrm{ml})$} & \multirow{4}{*}{$\begin{array}{c}\text { Dissolved } \\
\text { Hydrogen } \\
(\mathrm{mg} / \mathrm{L})\end{array}$} & \multirow{4}{*}{ Remarks } \\
\hline \multirow{3}{*}{$\begin{array}{l}\text { Mixing Ratio } \\
\text { (SE:RW) }\end{array}$} & \multicolumn{5}{|c|}{$\mathrm{pH}$ Value } & & \\
\hline & \multicolumn{5}{|c|}{ Addition of Oxidant and Reductant } & & \\
\hline & Additive-free & $\begin{array}{l}\text { Citric acidss }{ }^{1)} \\
\left(\mathrm{C}_{6} \mathrm{H}_{8} \mathrm{O}_{7}\right)\end{array}$ & $\begin{array}{l}\text { pH-reducing- } \\
\text { agent }^{2)}\end{array}$ & $\begin{array}{l}\text { Bicarbonate of soda }{ }^{3)} \\
\quad\left(\mathrm{NaHCO}_{3}\right)\end{array}$ & $\begin{array}{l}\text { Magnesium }{ }^{4)} \\
(\mathrm{Mg})\end{array}$ & & \\
\hline $\begin{array}{c}2.5: 7.5 \\
\text { Initial Conc. } \\
0.63 \% \\
\text { End Conc. } \\
0.86 \%\end{array}$ & 7.82 & 2.64 & 1.98 & 3.10 & 7.40 & 0.6 & $\begin{array}{l}\text { 1) } 1.5 \mathrm{~g} \\
\text { 2) } 1.4 \mathrm{ml}^{\star} \\
\text { 3) } 0.5 \mathrm{~g} \\
\text { 4) } 7.0 \mathrm{~g}\end{array}$ \\
\hline $\begin{array}{c}\text { 2.0: } 8.0 \\
\text { Initial Conc. } \\
0.61 \% \\
\text { End Conc. } \\
0.80 \%\end{array}$ & 6.39 & 2.64 & 1.94 & 3.83 & 7.40 & 0.7 & $\begin{array}{l}\text { 1) } 1.5 \mathrm{~g} \\
\text { 2) } 1.6 \mathrm{ml} \\
\text { 3) } 0.5 \mathrm{~g} \\
\text { 4) } 7.0 \mathrm{~g}\end{array}$ \\
\hline $\begin{array}{c}1.5: 8.5 \\
\text { Initial Conc. } \\
0.35 \% \\
\text { End Conc. } \\
0.68 \%\end{array}$ & 7.76 & 2.71 & 1.94 & 3.03 & 7.40 & 0.7 & $\begin{array}{l}\text { 1) } 1.5 \mathrm{~g} \\
\text { 2) } 1.6 \mathrm{ml} \\
\text { 3) } 0.5 \mathrm{~g} \\
\text { 4) } 7.0 \mathrm{~g}\end{array}$ \\
\hline $\begin{array}{c}\text { 1.0: } 9.0 \\
\text { Initial Conc. } \\
0.16 \% \\
\text { End Conc. } \\
0.55 \%\end{array}$ & 7.69 & 2.78 & 1.94 & 3.41 & 7.40 & 0.6 & $\begin{array}{l}\text { 1) } 1.5 \mathrm{~g} \\
\text { 2) } 1.6 \mathrm{ml} \\
\text { 3) } 0.5 \mathrm{~g} \\
\text { 4) } 7.0 \mathrm{~g}\end{array}$ \\
\hline $\begin{array}{c}0.5: 9.5 \\
\text { Initial Conc. } \\
0.12 \% \\
\text { End Conc. } \\
0.52 \%\end{array}$ & 7.01 & 2.82 & 1.94 & 3.24 & 7.40 & 0.7 & $\begin{array}{l}\text { 1) } 1.5 \mathrm{~g} \\
\text { 2) } 1.6 \mathrm{ml} \\
\text { 3) } 0.5 \mathrm{~g} \\
\text { 4) } 7.0 \mathrm{~g}\end{array}$ \\
\hline
\end{tabular}

SW: Sea Water; RW: Rain Water; ${ }^{*}$ The dosage of pH-reducing-agent was added in small amounts to be within $0.9 \%$ (blood conc.) for end concentration of the water.

In this experiment, the "pH-reducing-agent" was also used in addition to the citric acid as an oxidizing agent in strong consciousness of the sterilization.

Here, we take a look at both the "hydrochloric acid" and "sulphuric acid" included in the "pH-reducing-agent." That is, it is about a chemical reaction between the "magnesium (Mg)" and the "two acids" mentioned above.

First, we take up the "sulphuric acid". This acid is the one in which the hydrogen chloride $(\mathrm{HCl})$ was dissolved in water. This becomes the ions such as $\mathrm{H}^{+}$ and $\mathrm{Cl}^{-}$(i.e., hydrochloric acid: $\mathrm{HCl}$ ). When the Magnesium $(\mathrm{Mg})$ is added to the mixed water, it is changed into the two ions $\left(\mathrm{Mg}^{2+} \& 2 \mathrm{e}^{-}\right) . \mathrm{Mg}^{2+}$ ions are bonded to $\mathrm{Cl}^{-}$ion and became the magnesium chloride $\left(\mathrm{MgCl}_{2}\right) .2 \mathrm{e}^{-}$ions are bonded to $\mathrm{H}^{+}$ion and became the hydrogen $(\mathrm{H})$. And the hydrogen $(\mathrm{H})$ becomes the bubble by the magnesium chloride $\left(\mathrm{MgCl}_{2}\right)$ in the water solution. By the way, we can make a "battery" by adding the path of an electron (-) to the water solution. In other words, the connection of both carbon rod and $\mathrm{Mg}$ rod in the water 
Table 2. Result of the water quality (Ratio of mixed water (1:9)).

\begin{tabular}{|c|c|c|c|c|}
\hline Water quality items & Measured value & $\begin{array}{l}\text { WHO Standard } \\
\text { (including proposal) }\end{array}$ & Judgement & Remarks \\
\hline $\mathrm{Mg}^{2+}(\mathrm{mg} / \mathrm{L})$ & 2000 & $(\leq 300$ [Japan] $)$ & {$[\mathrm{O}]$} & $\begin{array}{c}\mathrm{mEq} / \mathrm{L} \text { (Co-written } \\
\text { recommendation) }\end{array}$ \\
\hline $\mathrm{pH}$ & 7.4 & - & {$[\mathrm{O}]$} & \\
\hline Dissolved Hydrogen (mg/L) & 0.6 & 0.5 & [O] & New \\
\hline ORP $(\mathrm{mV})$ & -90 & $\leq-50^{\text {मt }}$ & {$[\mathrm{O}]$} & $"$ \\
\hline Salinity $\mathrm{Cl}^{-}(\mathrm{mg} / \mathrm{L})$ & 1600 & $(\leq 200[$ Japan] $)$ & {$[\mathrm{O}]$} & $\begin{array}{l}\mathrm{mEq} / \mathrm{L} \text { (Co-written } \\
\text { recommendation) }\end{array}$ \\
\hline TOC (mg/L) & $1-7$ [Estimated] & - & {$[\mathrm{O}]$} & \\
\hline $\mathrm{NO}_{2}^{-} \quad(\mathrm{mg} / \mathrm{L})$ & 0.016 & $\leq 0.04$ & [O] & $\begin{array}{l}\mathrm{mEq} / \mathrm{L} \text { (Co-written } \\
\text { recommendation) }\end{array}$ \\
\hline $\mathrm{NO}_{2}^{-} \quad \& \quad \mathrm{NO}_{3}^{-} \quad(\mathrm{mg} / \mathrm{L})$ & 0.3 & $\leq 10$ & [O] & $"$ \\
\hline $\mathrm{Ca}^{2+}(\mathrm{mg} / \mathrm{L})$ & 0.4 & $\leq 300$ & {$[\mathrm{O}]$} & $"$ \\
\hline No. of General Bacteria (CFU/mL) & 13 & $\leq 100$ & {$[0]$} & \\
\hline No. of Colitics Germ Logions (CFU/mL) & ND & ND & {$[\mathrm{O}]$} & \\
\hline No. of Vibrio vulnificus (CFU/mL) & $0-100$ [Estimated] & ND & {$[\mathrm{O}]$} & \\
\hline Bisphenol A BPA $(\mu \mathrm{g} / \mathrm{L})$ & 0.045 [Estimated] & 125 & [O] & \\
\hline $\mathrm{Hg}(\mathrm{ng} / \mathrm{L})$ & 0 - 16 [Estimated] & $<500$ & {$[\mathrm{O}]$} & New \\
\hline $\mathrm{Cd}(\mathrm{ng} / \mathrm{L})$ & 0 - 82 [Estimated] & $<3000$ & [O] & $"$ \\
\hline Norovirus (copy/L) & $6-170 \Delta$ [Estimated] & ND & {$[\Delta]$} & $"$ \\
\hline 2019-nCoV (copy/L) & $941 \nabla$ [Estimated] & ND & {$[\Delta]$} & $"$ \\
\hline SARS-CoV (copy/L) & $"$ & $\mathrm{ND}$ & {$[\Delta]$} & $"$ \\
\hline MERS-CoV (copy/L) & $"$ & ND & {$[\Delta]$} & $"$ \\
\hline Flu Virus (MPN/mL) & $5-79 \square$ [Estimated] & ND & {$[\Delta]$} & $"$ \\
\hline
\end{tabular}

※ Estimated values on fungi $\rightarrow$ we regard $\mathrm{pH}$ of the treated mixed water as that of gastric fluid (cf. $\mathrm{pH}$ of hydrochloric acid: 1 - 2). The verification by the data is needed after this. 3 It is said that the development of therapeutic effect appears in $-100 \mathrm{mV}$ or less in the medical field [31]. $\boldsymbol{\Delta}$ This value is an example of the effluent after treating the wastewater. It is said that the Norovirus in winter exist in the state of being of the same level or more as the sewage effluent in the river-water and the seawater [32]. $\boldsymbol{\nabla}$ This value is the one detected from the sewage influent of the water regeneration center (Northern region), at Yokohama, Japan in April 2020 [33]. In addition, the value of 13.6 copy/g is detected from the sediments at the same place. The concentration of the virus geNome detected from the sewage water is extremely low. In addition, it is said that there was No detection from the sewage effluent [34].

solution is established and the battery is made.

Next, we take up the "hydrochloric acid." It is considered that there is no generation of the magnesium sulfate $\left(\mathrm{MgSO}_{4}\right)$ due to the reaction between the "hydrochloric acid" and the "magnesium (Mg)." That is the reason why it is thought that first, $\mathrm{H}_{2} \mathrm{O}$ and $\mathrm{H}^{+}$(ionization of $\mathrm{HCl}$ ) reacts and then the oxonium ions $\left(\mathrm{H}_{3} \mathrm{O}^{+}\right)$or hydroxonium ions $\left(\mathrm{H}_{3} \mathrm{O}^{+}\right)$are produced. In addition, $\mathrm{H}_{3} \mathrm{O}^{+}$is a monohydrate of $\mathrm{H}^{+}$, and $\mathrm{H}^{+}$makes the $\mathrm{H}_{3} \mathrm{O}^{+}$by hydration reaction. By the way, $\mathrm{H}_{3} \mathrm{O}^{+}$has a shape of trigonal bipyramid $\left(\angle \mathrm{H}-\mathrm{O}-\mathrm{H}\right.$ : around $\left.115^{\circ}\right)$ with the $\mathrm{O}$-atoms of $\mathrm{H}_{2} \mathrm{O}$ as an apex. And it is known that there exist the form of the wa- 
ter combined with the $\mathrm{H}_{3} \mathrm{O}^{+}$further such as (1) $\mathrm{H}_{5} \mathrm{O}_{2}^{+}$, (2) $\mathrm{H}_{7} \mathrm{O}_{3}^{+}$and (3) $\mathrm{H}_{9} \mathrm{O}_{4}^{+}$ etc. Incidentally, $\mathrm{H}_{5} \mathrm{O}_{2}^{+}$is the one in which the $\mathrm{O}$-atoms of $\mathrm{H}_{2} \mathrm{O}$ are bonded by the $\mathrm{H}$-atoms of the $\mathrm{H}_{3} \mathrm{O}^{+}$(hydrogen bond). Strictly speaking, these three types (1) - (3)) are called oxonium ions. When the degree of hydration is not clear, then it is generically called "hydronium ions $\left(\mathrm{H}_{3} \mathrm{O}^{+}\right)$".

The keyword in this experiment is Magnesium $(\mathrm{Mg})$. As the title of the paper suggests, it is because we examine the possibility of mixed water as a drinking water from the viewpoint of the formation of hydrogen-rich water. That is, the perspective of the generation of the hydrogen $\left(\mathrm{H}_{2}\right)$ by the Magnesium $(\mathrm{Mg})$ is an important point. The magnesium is the superiority of the vibration absorption. Therefore, the vibration $(116 \mathrm{~Hz},-48 \mathrm{dBm} /$ irradiation time: around $90 \mathrm{~min}$.) was irradiated to accelerate a generation amount of the hydrogen in this experiment. This vibration literally repeats going in and out of a solvent like a wave over and over again." It is thought that the vibration synchronizes with a flow of the solvent (solute) without noticing, and promotes the water ionization (strengthening of the electrolytes [solvent \& solute]), and further, contributes to the generating promotion effect of the dissolved hydrogen (DH). In addition, the decrease of the magnesium $(\mathrm{Mg})$ was around $0.1 \mathrm{~g}-0.2 \mathrm{~g} / \mathrm{one}$ time.

By the way, it is thought that the generated compounds (Magnesium-analogous compound) are probably divided into three patterns. The first pattern is "Magnesium hydroxide $\left(\mathrm{Mg}(\mathrm{OH})_{2}\right)$ ", the second one, "Magnesium chloride $\left(\mathrm{MgCl}_{2}\right)$ " and the third one, "Magnesium citrate $\left(\mathrm{MgC}_{6} \mathrm{H}_{6} \mathrm{O}_{7}\right)$ ".

Regarding the first one, if we drink the hydrogen water generated through the $\mathrm{Mg}$, the magnesium hydroxide $\left(\mathrm{Mg}(\mathrm{OH})_{2}\right)$ is also taken by that. However, the magnesium is necessary for human beings to live as a kind of mineral. It plays a principal role that the function of secreting the hormone or moving one's muscles is not carried out without " $\mathrm{Mg}$ ". It is said that if we of course take in excessive amount of it, some of the symptoms such as vomiting and diarrhea etc. appear, but there are mostly no case of excessive consumption. This is because the average daily intake of $\mathrm{Mg}$ for Japanese is $255 \mathrm{mg}$ [Male] and $225 \mathrm{mg}$ [Female], and the values are less than a guide standard $(340 \mathrm{mg}$ [Male] and $270 \mathrm{mg}$ [Female]). In addition, it is said that the amount of $\mathrm{Mg}$ included in hydrogen water generated by $\mathrm{Mg}$ is around $4 \mathrm{mg} / \mathrm{L}$ [35]. And Prof. D.M. K. Yokota (The Jikei University School of Medicine) has stated that the Mg component included in the sea salt (unrefined salt) makes the cluster of water molecular smaller, and that as a result, the oxygen dissolved between the two clusters comes out easily, and the fishes which live there can be easily respirated. However, the decrease of the oxygen concentration occurs in the household salt (refined salt), and the living things which live there cannot live a long life (Intent) [36].

Regarding the second one, there is a marketed product of drinking water in a plastic bottle (named SPORTS DRINK). The magnesium chloride $\left(\mathrm{MgCl}_{2}\right)$ and acidulants are appropriately included in this water [37]. By the way, we would like to confirm the "chloride ions" which are related to the experiment here a lit- 
tle bit more. In Japan, the Oral Rehydration Solution (ORS) as "special-use food" for heatstroke patients has been at present developed and sold at the pharmacy etc. This beverage includes the chlorine of $1770 \mathrm{mg} / \mathrm{L}(0.177 \%)$. This has around the same concentration as the salinity (ratio of the mixed water $\rightarrow 1: 9$ ) which shows as an example in Table 1 in the experiment this time. Incidentally, this beverage includes the "sodium citrate $\left(\mathrm{Na}_{3} \mathrm{C}_{6} \mathrm{H}_{5} \mathrm{O}_{7}\right)$ ", "magnesium chloride $\left(\mathrm{MgCl}_{2}\right)$ " and "salt equivalent" etc. except for the "chlorine" mentioned above. In addition to that, there is another drinking water in plastic bottle (named AQUARIUS). This is not a food for patients. This one is a beverage with high $\mathrm{Na}, \mathrm{K}$ etc. concentration, and is available on a general market except the pharmacy unlike that mentioned above. And now, regarding the two patterns mentioned above, it is said as a general characteristic of the magnesium $(\mathrm{Mg})$ that when a proper amount of water is exposed to the $\mathrm{Mg}$, the water is broken down, and that both the hydrogen and the oxygen are generated by the reaction with the Mg. And it is also said that the Mg reacts the water in the water solution including the chloride and forms the magnesium hydroxide $\left(\mathrm{Mg}(\mathrm{OH})_{2}\right)$ generating the hydrogen gas $\left(\mathrm{H}_{2}\right)$ [38]. The chemical reaction is as follows.

$$
\mathrm{Mg}+2 \mathrm{H}_{2} \mathrm{O} \rightarrow \mathrm{Mg}(\mathrm{OH})_{2}+\mathrm{H}_{2}
$$

And, reacting the hydrochloric acid $(\mathrm{HCl})$ with magnesium hydroxide $\left(\mathrm{Mg}(\mathrm{OH})_{2}\right)$, the magnesium chloride $\left(\mathrm{MgCl}_{2}\right)$ is produced.

$$
\mathrm{Mg}(\mathrm{OH})_{2}+2 \mathrm{HCl} \rightarrow \mathrm{MgCl}_{2}+2 \mathrm{H}_{2} \mathrm{O}
$$

As $\mathrm{Mg}(\mathrm{OH})_{2}$ is a weak acid, the degree of ionization $(\alpha)$ becomes $0<\alpha<1$.

Therefore, both $\mathrm{Mg}^{2+}$ and $\mathrm{OH}^{-}$exist in the water. For example, considering that the half of the $\mathrm{Mg}(\mathrm{OH})_{2}$ ionizes, and becomes both $\mathrm{Mg}^{2+}$ and $2 \mathrm{OH}^{-}$at this time, i.e., that the reaction such as Equation (3) occurs, a reaction formula such as Equation (4) is obtained.

$$
\begin{aligned}
& \mathrm{Mg}(\mathrm{OH})_{2} \rightleftarrows \mathrm{Mg}^{2+}+2 \mathrm{OH}^{-} \\
& \mathrm{H}^{+}+\mathrm{OH}^{-} \rightleftarrows \mathrm{H}_{2} \mathrm{O}
\end{aligned}
$$

Therefore, the $\mathrm{OH}^{-}$is canceled by the reaction as found in Equation (4).

However, as $\mathrm{H}^{+}$which has no response to this $\left(\mathrm{OH}^{-}\right)$still remains the half of it, $\mathrm{H}^{+}$in the solution becomes a bit large. It means a weak acidity. On the other hand, as $\mathrm{HCl}$ shown in Equation (2) is a strong acidity, the degree of ionization ( $\alpha$ ) becomes 1. As a result, the all becomes $\mathrm{H}^{+}$and $\mathrm{Cl}^{-}$(See Equation (5))

$$
2 \mathrm{HCl} \rightarrow 2 \mathrm{H}^{+}+2 \mathrm{Cl}^{-}
$$

Regarding the third one, adding the citric acid into the magnesium hydroxide $\left(\mathrm{Mg}(\mathrm{OH})_{2}\right) /$ the magnesium $(\mathrm{Mg})$, the following reaction occurs.

$$
\begin{gathered}
\mathrm{C}_{6} \mathrm{H}_{8} \mathrm{O}_{7}+\mathrm{Mg}(\mathrm{OH})_{2} \rightarrow \mathrm{MgC}_{6} \mathrm{H}_{6} \mathrm{O}_{7}+\mathrm{H}_{2} \mathrm{O} \\
\mathrm{C}_{6} \mathrm{H}_{8} \mathrm{O}_{7}+\mathrm{Mg} \rightarrow \mathrm{MgC}_{6} \mathrm{H}_{6} \mathrm{O}_{7}+\mathrm{H}_{2}
\end{gathered}
$$

By the way, the magnesium (Mg: metal mineral) is not soluble in water (insolubility). However, the Mg becomes a citrate (magnesium citrate) after adhering 
to the citric acid and it becomes the water soluble by the chelate effect. As a result, it becomes easy to absorb in the water. The citric acid encases the magnesium $(\mathrm{Mg})$ and protects it from the oxidation. That is, it can be said that the magnesium citrate $\left(\mathrm{MgC}_{6} \mathrm{H}_{6} \mathrm{O}_{7}\right)$ is a compound which prevents the oxidation. In other words, it means not to make the oxide coating film (black) on Mg. Therefore, it is possible to remove the film formed on the surface of the Mg. Due to this, as the $\mathrm{Mg}$ itself is also dissolved into the water with the film removal, the particle size of the Mg becomes a bit small. However, it is thought that this is a very important phenomenon from the viewpoint of the readily re-available $\mathrm{Mg}$.

Figure 1 shows the result of the change of $\mathrm{pH}$ by the oxidant and reductant at each salinity concentration level in the mixed water (ratio $\rightarrow 1: 9$ ). This time, the change of the $\mathrm{pH}$ using both the oxidant ((1) Citric acid $\left[\mathrm{C}_{6} \mathrm{H}_{8} \mathrm{O}_{7}\right]$, (2) pH-reducing agent) and the reductant ((1) Bicarbonate of soda $\left[\mathrm{NaHCO}_{3}\right]$, (2) Magnesium $(\mathrm{Mg})$ in the mixed water with the five kinds of the salinity concentration was examined. As is seen from Figure 1, first $1.5 \mathrm{~g} / 100 \mathrm{~mL}$ of "citric acid $\left[\mathrm{C}_{6} \mathrm{H}_{8} \mathrm{O}_{7}\right]$ (O)" as no. 2 (processing order) was added into the mixed water, and then the $\mathrm{pH}$ was reduced to $2.64-2.82$. In addition, it is said that the acceptable daily intake (ADI) per person of the citric acid is $15 \mathrm{~g} / \mathrm{L}$ [39]. Due to the corona pandemic in the world, the news reports say on a daily basis that more people are infected with the coronavirus (COVID-19). Under the circumstances mentioned above, we have had a strong awareness of the sterilization effect. Then this value was set up in a strong oxidation state. Therefore, the $1.4 \mathrm{~mL}-1.6 \mathrm{~mL}$ of " $\mathrm{pH}$-reducing-agent $(\Delta)$ " as no. 3 (processing order) was added to the water to adjust the $\mathrm{pH}$ under highly acidic condition like gastric acid, and was placed calmly for one hour for its bactericidal effect. After that, the $0.5 \mathrm{~g} 0 / 100 \mathrm{~mL}$ of "bicarbonate of soda ( $\boldsymbol{\nabla})$ " as no. 4 (processing order) was added to the water to try a gradual rise in the $\mathrm{pH}$ of 3.03 - 3.83. In addition, it is said that the acceptable daily intake (ADI) per person of the bicarbonate of soda is $5 \mathrm{~g} / \mathrm{L}[40]$. And after confirming the rising of the $\mathrm{pH}$, the $7 \mathrm{~g}$ of the "magnesium $(\mathrm{Mg})$ " $(\diamond)$ as no. 5 (processing order) was added to the water. The numbers $(1-5)$ shown in Figure are the processing orders (i.e., no. 1 - no. 5). In addition, the number of " 1 " shows the state of "Additive-free ( $\boldsymbol{\square})$ " as no. 1 (processing order). As we said earlier, when putting the metal magnesium $(\mathrm{Mg})$ to the water, the $\mathrm{Mg}$ reacts with the water $\left(\mathrm{H}_{2} \mathrm{O}\right)$, and generates both the magnesium hydroxide $\left(\mathrm{Mg}(\mathrm{OH})_{2}\right)$ and the hydrogen gas $\left(\mathrm{H}_{2}\right)$ under the reaction. At that time, the magnesium hydroxide $\left(\mathrm{Mg}(\mathrm{OH})_{2}\right)$ is completely ionized into the magnesium ions $\left(\mathrm{Mg}^{2+}\right)$ and the hydroxide ions $\left(\mathrm{OH}^{-}\right)$in the water. And the higher the rate gets (i.e., the higher the hydroxide ion concentration gets), the higher value $\mathrm{pH}$ becomes. Figure 1 shows this phenomenon clearly. Here the reaction ( $\mathrm{pH}$ increase) in $90 \mathrm{~min}$. was observed in the water. In the experiment, the supernatant liquid was sucked from the upper part of the water in the experimental container at around 7.4 of the value of $\mathrm{pH}$ (human's blood equivalent value). And the hydrogen concentration (DH:mg/L) of that liquid was measured. 


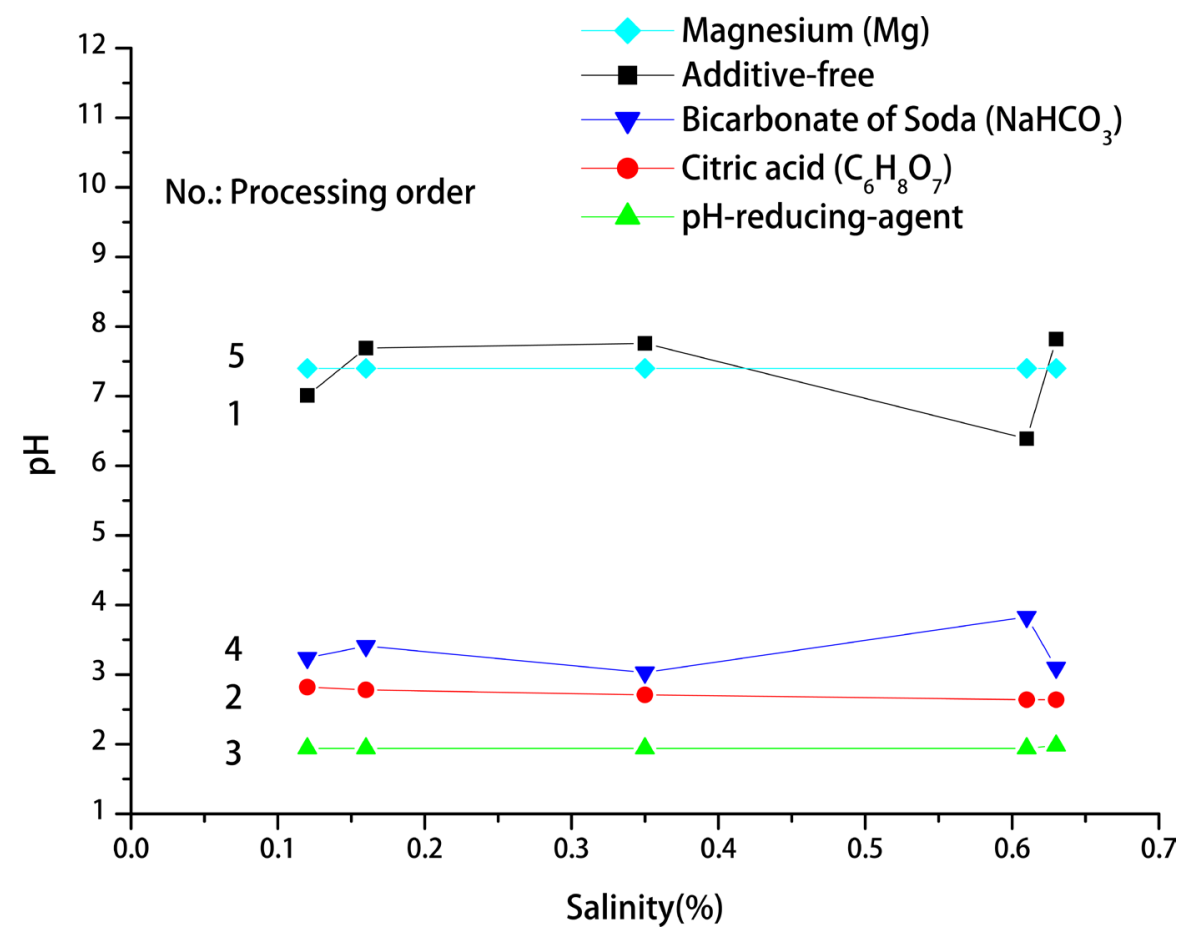

Figure 1. Change of $\mathrm{pH}$ by the oxidant and reductant at each salinity concentration level.

Figure 2 shows the relation between each salinity concentration and ORP.

In general, the Oxidation-Reduction Potential (ORP) is expressed by a potential difference which is a difference between the power in which a substance oxidizes another substance (oxidant activity) and the one in which reduces another one (reductive activity). The ORP is expressed by plus (+: oxidant) and minus (-: reductive), and then the unit is $\mathrm{mV}$. The higher the value of plus $(+)$, the stronger the oxidation power which means bonding power with oxygen, hydrogen discharge power, electron emission power and increased power of oxidation number is. On the other hand, the higher the value of minus (-) is, the stronger the reduction power which means emission power with oxygen, hydrogen bonding power, electron receiving power and decreased power of oxidation number is. It means that if ORP is low, the reductant is strong. i.e., anti-oxidizing power exists. It is said that the water whose oxidation power (rusting force) is weak is good regarding the water accepted into body, too. We sometimes call the water with low ORP "reducing water" or "hydrogen water". This time the difference of the reduction power due to the difference of salinity concentration was confirmed by measuring the ORP at each salinity concentration of the mixed water. This is because the ORP is also related to the amount of the dissolved hydrogen (DH) which is a key word in this paper. Looking at the relation between each salinity concentrations (5 kinds) and the ORP, the value of the ORP at all the concentration is relatively low like $-78 \mathrm{mV}--93 \mathrm{mV}$. This shows that all 5 kinds of water have a certain degree of reduction power. It is understood from Figure 2 that the value of the ORP increases (-) with a decrease in salinity concentration. This figure shows that when the salinity concentration is the lowest value $(0.12 \%)$, the ORP is the 
lowest one $(-90 \mathrm{mV})$. This means that the reduction effect is the largest. In addition, it is said that the value of the ORP having the medical effects is less than $-100 \mathrm{mV}[33]$.

Figure 3 shows the result of amount of the Dissolved Hydrogen (DH) at each salinity concentration of the mixed water.

We examine the relation between the salinity concentration and the ORP in Figure 2. The relation between the salinity concentration and the Dissolved

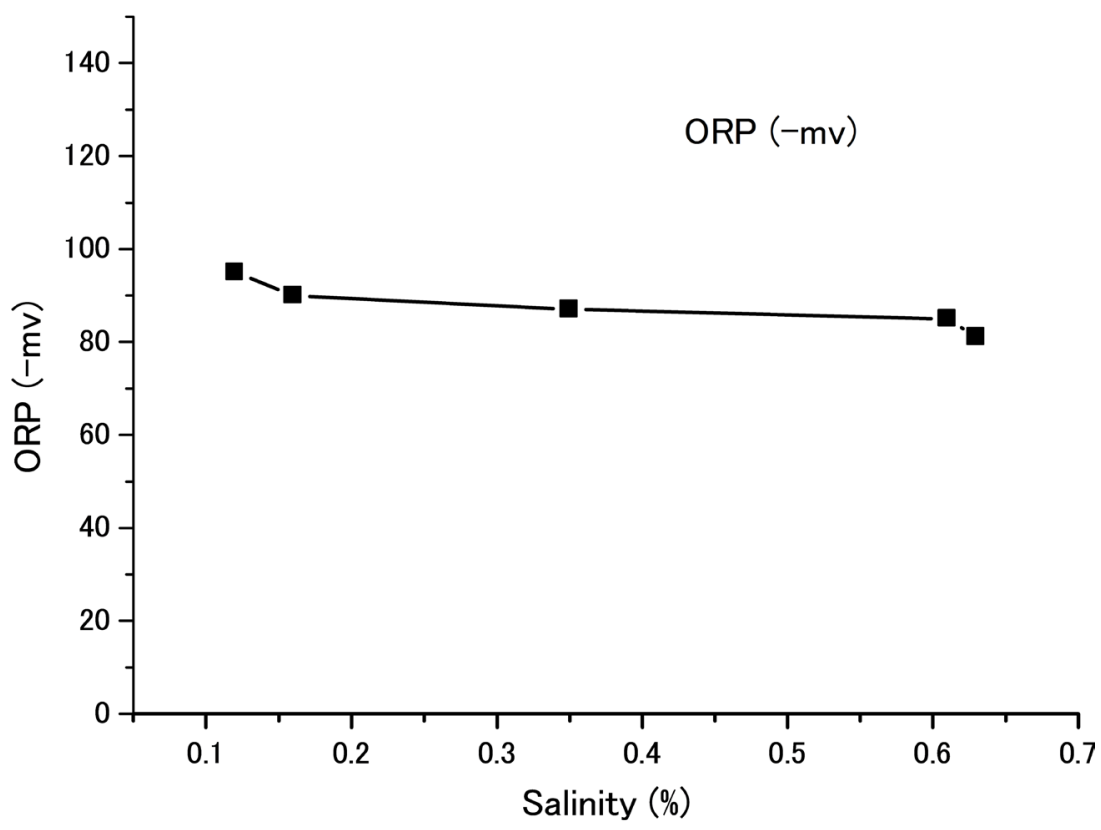

Figure 2. Relation between each salinity concentration and ORP.

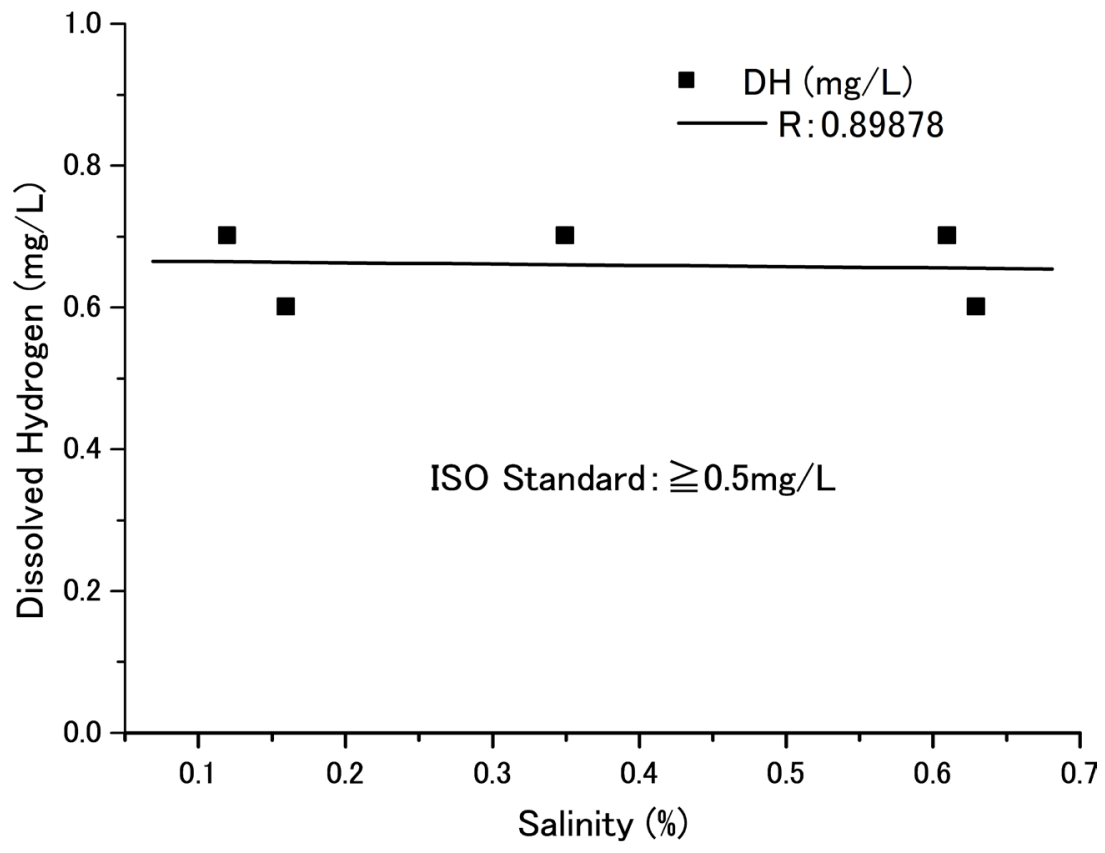

Figure 3. Amount of the Dissolved Hydrogen $[\mathrm{DH}]$ at each salinity concentration of the mixed water. 
Hydrogen (DH) also shows the similar tendency which is seen in Figure 3. That is, DH also increases (+) a bit with a decrease of salinity concentration. Incidentally, comparing the value of the DH with the ISO standard, it is understood that all the $\mathrm{DHs}$ meet the standard $(0.5 \mathrm{mg} / \mathrm{L})[41]$ at all the salinity concentrations.

Summarizing the above, it is considered that the compounds contained in the mixed water obtained from the experiment are aqueous solutions including the chlorohydroxy magnesium $(\mathrm{Mg}(\mathrm{OH}) \mathrm{Cl})$ which was combined by both the magnesium hydroxide and magnesium chloride. The chemical reaction is as follows. (See Equation (8)) And it is considered that the magnesium citrate $\left(\mathrm{MgC}_{6} \mathrm{H}_{6} \mathrm{O}_{7}\right)$ plays an important part to prevent the formation of the oxide film of $\mathrm{Mg}$.

$$
\mathrm{Mg}(\mathrm{OH})_{2}+\mathrm{MgCl}_{2} \rightarrow 2 \mathrm{Mg}(\mathrm{OH}) \mathrm{Cl}
$$

Regarding the liquidity of the mixed water $(\mathrm{Mg}(\mathrm{OH}) \mathrm{Cl})$ obtained in the experiment, it is thought that the reaction as "alkalinity" occurs more easily than that as "acidity". The reason can be imagined in the following reaction.

$$
\begin{gathered}
\operatorname{MgCl}(\mathrm{OH})(\mathrm{S}) \rightleftarrows \mathrm{Mg}(\mathrm{OH})^{+} \\
\text {Alkalinity: } \mathrm{Mg}(\mathrm{OH})^{+} \rightleftarrows \mathrm{Mg}^{2+}+\mathrm{OH}^{-} \\
\text {Acidity }: \mathrm{Mg}(\mathrm{OH})^{+}+\mathrm{H}_{2} \mathrm{O} \rightleftarrows \mathrm{Mg}(\mathrm{OH})_{2}(\mathrm{aq})+\mathrm{H}^{+}
\end{gathered}
$$

It is considered that if one wants to dilute the concentration of the mixed water $(\mathrm{Mg}(\mathrm{OH}) \mathrm{Cl})$, the centrifugalizing $(3500 \mathrm{rpm} / 5 \mathrm{~min}$.) is good to do it. This centrifugalizing method is a commonly used technique in the medical field to check the "component" in blood after taking out the "serum" which was left after the cell compounds such as erythrocyte and so on were removed from a blood. This time, the filtration using ceramic filter was conducted as a very simple way. By the way, the research on the effect of hydrogen (and hydrogen water) has been proceeded for a lot of animals (mouse, guinea pig etc.) and humans. As for the topic for humans, the paper on a restraint of severity and an improvement of the dyspneic etc. for the infected patients of the coronavirus (COVID-19) by the inhalation of hydrogen gas has been presented in 2020, June. The paper is as follows. Wei-Jie Guan et al. (2020) Hydrogen/oxygen mixed gas inhalation improves disease severity and dyspnea in patients with Coronavirus disease 2019 in a recent multicenter, open-label clinical trial], Journal of Thoracic Disease, 12(6):3448-3452 [42]. On the other hand, as for the topic for animals, a paper on the effectiveness of the hydrogen water for the fish was reported for the first time in the world in 2017. The paper is as follows. Hu Z. et al. (2017) Impact of molecular hydrogen treatments on the innate immune activity and survival of zebrafish (Danio rerio) challenged with Aeromonas hydrophila, Fish Shellfish Immunol. Aug; 67: 554-560 [43]. The used fish was a zebra fish (around $5 \mathrm{~cm}$ ). It is said, as a result, that when the zebra fish is raised in the water with the hydrogen concentration of a bit of $0.016 \mathrm{mg} / \mathrm{L}$, the natural immunity of the fish is strengthened, and at the same time the life span has also increased even if the fish is infected with bacteria. Showing the effectiveness for the fish this time, 
it is understood that the hydrogen is effective for higher forms of life widely. Authors has tried a bioassay (Japanese killifish) by very simple visual confirmation (>two weeks) using the "hydrogen water" generated from the mixed water. As a result, we could not see any particular abnormalities about the bioassay obtained. Regarding this, it is necessary to verify the bioassay in detail in the future. And we have not thought about making some animal experiments yet at this stage.

\section{Conclusion}

In exploring an autonomous independent water supply system, authors have realized the importance of the sustainable water supply utilizing regional features in isolated islands. This paper is further study from the previous one. This time we have narrowed down the mixing rate of mixed water. In this study, the mixed water less than $0.74 \%$ (blood concentration) has been prepared first, and then divided it into five kinds of the mixing rate of mixed water. And we have compared and examined the characteristics of the mixed water from the viewpoint of the relationship between salinity and $\mathrm{pH}$, ORP and that of Dissolved Hydrogen, and examined the possibility of mixed water as a drinking water. As a result, we have obtained the new findings that suggest the possibility. We would like to research the way to change raw seawater into drinking water from now on.

\section{Acknowledgements}

In carrying out our study, Dr. Imamura A. supported us for doing the experiment. So we would like to express publicly here our deepest appreciation for his help and support.

\section{Conflicts of Interest}

The authors declare no conflicts of interest regarding the publication of this paper.

\section{References}

[1] Mithen, S. (2012) Thirst: Water and Power in the Ancient World. Harvard University Press, Cambridge, MA.

[2] Japanese Cabinet Office (2020) Investigation on Changes in Consciousness of Life and Action under the Influence of the Corona Virus Disease 2019. https://www5.cao.go.jp/keizai2/manzoku/pdf/shiryo2.pdf

[3] Hashimoto, J. (2019) The Impact of Privatisation on the Sustainability of Water Resources. Iwanami Shoten, Japan.

[4] Matome, R. (2016) Nihon no Nougyou (Japanese Agriculture). https://rekishi-memo.net/japan column/nougyou.html

[5] National Chamber of Agriculture (2018) Establishment of Agricultural Corporation. 3rd Edition, National Chamber of Agriculture Publishing Department, Tokyo.

[6] Life Lab Inc. (2019) Nihon no Nougyou Jinkou no Genjyou (Current Status of Ja- 
pan's Agricultural Population, Youth Farming Is Increasing! ).

https://www.sangyo.net/contents/myagri/agriculture-population.html

[7] Money Forward Bizpedia (2020) How to Start an Agricultural Corporation. https://biz.moneyforward.com/blog/23020/

[8] Diamond, J.M., Noah Harari, Y., Yoro, T., Fukuoka, S., Osawa, M., et al. (2020) Talking about the Post-Corona World-Modern Intellectuals' Eyes. Asahi Shinsho, Tokyo.

[9] Schumacher, E.F. (1973) Small Is Beautiful: Economics as If People Mattered. Blond \& Briggs, London.

[10] Hiratsuka, A. and Imamura, A. (2020). Study on Reduction of Mixed Water Salinity by Sound Wave toward Water Scarcity Issue-Solving in Isolated Islands in the World. Journal of Water Resources and Protection, 12, 155-170. https://doi.org/10.4236/jwarp.2020.122010

[11] Fukuoka, S. (2004) Is It Now Out of Danger to Eat the Cow? Bungeishunjū Ltd., Chiyoda.

[12] Fukuoka, S. (2007) Between Life and Lifeless Thing. Kodansha, Toyko.

[13] Hiratsuka, A., Tomonaga, Y., Wakae, K. and Yasuda, Y. (2018) Study on Sustainable Water Resource Conservation: Toward Deepening of Homo Environments. Journal of Water Resources and Protection, 10, 327-368. https://doi.org/10.4236/jwarp.2018.103019

[14] Kurihara Y. (1975) Finite Ecology-System of Stability and Coexistence. Iwanami Shoten, Tokyo. (In Japanese)

[15] Aichi Prefectural Institute of Public Health (2020) Vibrio Vulnificus Infection. https://www.pref.aichi.jp/eiseiken/67f/vulnificus.html\#b1

[16] https://kotobank.jp/word/

[17] Eiichiro Kuma (n.d.) Part 12. Salt Story (above) Salt Reduction Is Not Correct. http://www.ps-corp.co.jp/column/health/n012.html

[18] Aoki, K., Yamori, Y., Ooshima, A. and Okamoto, K. (1972) Effects of High and Low Sodium In-Take in Spontaneously Hypertensive Rats. Japanese Circulation Journal, 36, 539-545. https://doi.org/10.1253/jcj.36.539

[19] Aoki, K. (1986) Reversed Health Readers. PHP Institute, Kyoto.

[20] Ameba (n.d.) Intestinal Environment Advisor. https://ameblo.jp/shiawasehennkousenn/entry-11505389448.html

[21] NAIKAI (n.d.) History. http://www.naikai.co.jp/j hist.htm

[22] Colborn, T., Dumanoski, D. and Peterson Myers, J. (1996) Our Stolen Future: Are We Threatening Our Fertility, Intelligence and Survival? A Scientific Detective Story. Dutton Adult, New York City.

[23] Japan Meteorological Agency (2019). https://www.data.jma.go.jp/gmd/kaiyou/shindan/d 1/heavymetal/heavymetal.html

[24] Terashima, T. and Nishiwaki, S. (2020) COVID-19 Intensive Protection Book. Takarajimasha, Tokyo, 54.

[25] Fukuoka, S. (2012) Rukiboshi Kamakiri no Ao (Blue of Rosalia Batesi). Bunshun Shinsho, Tokyo.

[26] Kimura, M. (2007) Mineral in Sea Water and Health. Biomedical Research on Trace Elements, 18, 336-345.

[27] Hiratsuka, A., Tomonaga, Y. and Yasuda, Y. (2014) Environmental Anthropological Study of Watershed Management-Water Quality Conservation of Forest as a Cat- 
chment Area in the Southern Part of Australia, Journal of Water Resources and Protection, 6, 1691-1702. http://dx.doi.org/10.4236/jwarp.2014.618152

[28] Li, Y.-F., et al. (2014) Effects of Chlorination on Soul Chemical Properties and Nitrogen Uptake for Tomato Drip Irrigated with Secondary Sewage Effluent. Journal of Integrative Agriculture, 13, 2049-2060. https://doi.org/10.1016/S2095-3119(13)60692-9

[29] Hirashima, S. (2020) Is It the Key to Achieving the SDGs? Approaching the Possibility of "Seawater Agriculture". https://ampmedia.jp/2020/01/22/seawater/

[30] Kitano, M., et al. (2014) Characteristics of Nutrient Salt Uptake Associated with Water Use of Corn Catch Crop Field at Different Plant Densities in a Greenhouse. Pedosphere, 24, 339-348. https://doi.org/10.1016/S1002-0160(14)60020-5

[31] (2005) How "Miracle" Is the Commercial Product of Miraculous Water? https://kenyukan.at.webry.info/200506/article 5.html

[32] Hara, H. (2014) Kankyousui chuu no Norouirusu Bunseki Houhou (Analytical Method of Norovirus in Environmental Water). INET, 36, 8-9.

[33] Ogawa, H., et al. (2020) Kankyou sui Chosa ni yoru Shingata Korona Uirusu no Gesui kara no Kenshutsu (Detection of COVID-19 in Wastewater by Environmental Water Survey). IASR, 41, 122-123.

https://www.niid.go.jp/niid/ja/diseases/ka/corona-virus/2019-ncov/2488-idsc/iasrne ws/9714485p02.html

[34] Japanese Ministry of land Infrastructure, Transport and Tourism (2020). http://www.nilim.go.jp/lab/bcg/kisya/kako/journal/kisha100226.pdf

[35] Guide to the Function and Selection of Hydrogen Water to Know by Illness/Symptom. http://www.suisosui-maruwakarijitenn.com/choose/magnesium.html

[36] Yokota, K. (2006) Magunesium Health Readers. Gendai Shorin, Tokyo, 16-31.

[37] Amazom.com (n.d.) https://www.amazon.co.jp

[38] The Japan Magnesium Association (n.d.) Basic Knowledge of Magnesium: Safe Handling. http://magnesium.or.jp/property/safeuse/

[39] Nakano, K. (2019) How to Make Citric Acid Water (Edible) and How to Drink It Effectively? https://chisiki.xsrv.jp/aqueous-citric-acid/

[40] Hiraishi, T. (2020) Tansan sui-Sugoi Katsuyou Jyutsu (Carbonated Water-Great Practical Usage). Makino Shuppan, Tokyo, 12.

[41] Japanese Molecular Hydrogen Promotion Association. https://jhypa.org

[42] Guan, W.J., Wei, C.H., Chen, A.-L., Sun, X.C., Guo, G.Y., et al. (2020) Hydrogen/Oxygen Mixed Gas Inhalation Improves Disease Severity and Dyspnea in Patients with Coronavirus Disease 2019 in a Recent Multicenter, Open-Label Clinical Trial. Journal of Thoracic Disease, 12, 3448-3452. https://doi.org/10.21037/jtd-2020-057 http://jtd.amegroups.com/article/view/40994/html

[43] Hu, Z.Y., Wu, B.Q., Meng, F.H., Zhou, Z.J., Lu, H. and Zhao, H., Jin-Dong Shi and Pei-Zhen Lai (2017) Impact of Molecular Hydrogen Treatments on the Innate Immune Activity and Survival of Zebrafish (Danio rerio) Challenged with Aeromonas hydrophila. Fish and Shellfish Immunology, 67, 554-560.

https://www.ncbi.nlm.nih.gov/pubmed/28630014

https://doi.org/10.1016/j.fsi.2017.05.066 